\title{
A new species of Spirorchis MacCallum, 1918 (Digenea: Schistosomatoidea) and Spirorchis cf. scripta from chicken turtle, Deirochelys reticularia (Emydidae), with an emendation and molecular phylogeny of Spirorchis
}

\author{
Jackson R. Roberts ${ }^{1}$, Raphael Orélis-Ribeiro ${ }^{2}$, Kenneth M. Halanych $^{3}$, Cova R. Arias ${ }^{4}$ and Stephen A. Bullard ${ }^{1}$ \\ ${ }^{1}$ Aquatic Parasitology Laboratory, School of Fisheries, Aquaculture, and Aquatic Sciences, Auburn University, Auburn, Alabama, \\ USA; \\ ${ }^{2}$ Laboratório de Ecologia Molecular e Parasitologia Evolutiva, Universidade Federal do Paraná, Curitiba, Paraná, Brazil; \\ ${ }^{3}$ Auburn University, Department of Biological Sciences and Molette Biology Laboratory for Environmental \& Climate Change \\ Studies, Auburn, Alabama, USA \\ ${ }^{4}$ Aquatic Microbiology Laboratory, School of Fisheries, Aquaculture, and Aquatic Sciences, Auburn University, Auburn, Alabama, \\ USA
}

\begin{abstract}
Chicken turtles, Deirochelys reticularia (Latreille in Sonnini et Latreille) (Testudines: Emydidae) from Alabama, USA were infected by Spirorchis collinsi Roberts et Bullard sp. n. and Spirorchis cf. scripta. The new species is most easily differentiated from its congeners by the combination of having caeca that extend far beyond the genitalia, intercaecal genitalia positioned in the middle portion of the body, a testicular column that nearly abuts the caecal bifurcation, a cirrus sac positioned between the testes and ovary, a massive Mehlis' gland, an elongate, longitudinal metraterm that extends anteriad beyond the level of the ovary, a pre-ovarian genital pore, and a prominent, intercaecal Manter's organ. The specimens of S. cf. scripta differed from the holotype and published descriptions of Spirorchis scripta Stunkard, 1923 by several subtle morphological features, perhaps comprising intraspecific variation, but collectively warranted a detailed description herein. Based on examinations of the aforementioned specimens plus the holotype, paratypes and vouchers of morphologically-similar congeners, Spirorchis MacCallum, 1918 is emended to include the presence of oral sucker spines, a pharynx, lateral oesophageal diverticula ('plicate organ') and a median oesophageal diverticulum ('oeseophageal pouch'). Phylogenetic analysis of the nuclear large subunit rDNA (28S) recovered S. collinsi sister to Spirorchis picta Stunkard, 1923, >99\% similarity between S. cf. scripta and S. scripta, and a monophyletic Spirorchis MacCallum, 1918. No blood fluke infection has been reported previously from these drainages, Alabama, or this turtle species. This is the first new species of Spirorchis to be described from North America in 26 years.
\end{abstract}

Keywords: taxonomy, Spirorchiidae, Spirhapalum, 28S phylogeny, Baracktrema

Twenty two species of turtle blood flukes (TBF) ranging in North America are assigned to Spirorchis MacCallum, 1918, Hapalorhynchus Stunkard, 1922, Unicaecum Stunkard, 1925 and Vasotrema Stunkard, 1928. Collectively, they infect 16 species of freshwater turtles: four infect snapping turtles (Chelydridae), ten infect pond turtles (Emydidae), three infect mud/musk turtles (Kinosternidae) and five infect softshell turtles (Trionychidae) (see Platt 1993, 2002, Smith 1997a,b, Orélis-Ribeiro et al. 2014). One third (29 of $86 ; 34 \%$ ) of the freshwater turtle species in North America range in rivers and lakes of Alabama (van Dijk et al. 2014, Guyer et al. 2015) and three of the 13 (23\%) species of planorbid snails that range in Alabama (Johnson et al. 2013) are known to shed cercariae of Spirorchis spp. else- where (Wall 1939, 1940, 1941a,b, Pieper 1953, Goodchild and Kirk 1960, Holliman and Fisher 1968, Holliman et al. 1971). Yet, no TBF infection has been reported from a turtle or snail in Alabama and few (11 of 29; 38\%) turtles that occur there are known as TBF hosts elsewhere (Smith 1997a,b).

Parasitological examinations of two chicken turtles, Deirochelys reticularia (Latreille in Sonnini et Latreille) from Alabama rivers revealed infections by a new species of Spirorchis and Spirorchis cf. scripta. Herein, we describe these specimens and compare them to type materials of Spirorchis innominatus Ward, 1921 (type species), Spirorchis artericola (Ward, 1921), Spirorchis haematobius (Stunkard, 1922), Spirorchis elegans Stunkard, 
Table 1. Sequences of turtle blood flukes used in the present study.

\begin{tabular}{|c|c|c|c|c|}
\hline Turtle blood flukes & Host species & Locality & $\begin{array}{l}\text { GenBank } \\
\text { Accession } \\
\text { Numbers }(28 \mathrm{~S})\end{array}$ & Reference \\
\hline $\begin{array}{l}\text { Baracktrema obamai } \\
\text { Roberts, Platt et Bullard, } 2016\end{array}$ & $\begin{array}{l}\text { Siebenrockiella crassicollis } \\
\text { (Gray) }\end{array}$ & Perak (probably Perak River), Malaysia & KX061500 & Roberts et al. $2016 \mathrm{a}$ \\
\hline $\begin{array}{l}\text { Spirhapalum polesianum } \\
\text { Ejsmont, } 1927\end{array}$ & $\begin{array}{l}\text { Emys orbicularis } \\
\text { (Linnaeus) }\end{array}$ & Lesniki, Ukraine & AY604705 & Snyder 2004 \\
\hline $\begin{array}{l}\text { Spirhapalum siamensis } \\
\text { Tkach, Snyder et Vaughn, } 2009\end{array}$ & $\begin{array}{l}\text { Cuora amboinensis } \\
\text { (Riche in Daudin) }\end{array}$ & $16^{\circ} 42^{\prime} \mathrm{N} ; 98^{\circ} 34^{\prime} \mathrm{E}$, Mae Sot, Thailand & FJ481166 & Tkach et al. 2009 \\
\hline $\begin{array}{l}\text { Spirorchis artericola } \\
\text { (Ward, 1921) }\end{array}$ & $\begin{array}{l}\text { Chrysemys picta } \\
\text { (Schneider) }\end{array}$ & Reelfoot Lake, Tennessee, USA & AY604704 & Snyder 2004 \\
\hline Spirorchis collinsi sp. n. & $\begin{array}{l}\text { Deirochelys reticularia } \\
\text { (Latreille in Sonnini et } \\
\text { Latreille) }\end{array}$ & $\begin{array}{l}32^{\circ} 25^{\prime} 44^{\prime \prime N} \text {; } 85^{\circ} 38^{\prime} 45^{\prime \prime} \mathrm{W} \text {, Big Beaver Pond, near } \\
\text { Uphapee Creek, Tallapoosa River, Tuskegee, } \\
\text { Alabama, USA }\end{array}$ & KY091664 & Present study \\
\hline $\begin{array}{l}\text { Spirorchis haematobius } \\
\text { (Stunkard, 1922) }\end{array}$ & $\begin{array}{l}\text { Chelydra serpentina } \\
\text { (Linnaeus) }\end{array}$ & Missouri River, Fremont County, Iowa, USA & FJ481164 & Tkach et al. 2009 \\
\hline $\begin{array}{l}\text { Spirorchis picta } \\
\text { Stunkard, } 1923\end{array}$ & $\begin{array}{l}\text { Trachemys scripta } \\
\text { (Thunberg in Schoepff) }\end{array}$ & $\begin{array}{l}32^{\circ} 38^{\prime} 53^{\prime \prime N} \text {; } 85^{\circ} 29^{\prime} 07^{\prime \prime W} \text {, E.W. Shell Fisheries } \\
\text { Station, Tallapoosa River drainage, Auburn } \\
\text { University, Auburn, Alabama, USA }\end{array}$ & KY091665 & Present study \\
\hline $\begin{array}{l}\text { Spirorchis scripta } \\
\text { Stunkard, } 1923\end{array}$ & Trachemys scripta & $\begin{array}{l}\text { Moungers Creek, Pascagoula Bay drainage, } \\
\text { Vancleave, Mississippi, USA }\end{array}$ & AY222174 & Olson et al. 2003 \\
\hline Spirorchis cf. scripta & Deirochelys reticularia & $\begin{array}{l}32^{\circ} 25^{\prime} 44^{\prime \prime N} \text {; } 85^{\circ} 38^{\prime} 45^{\prime \prime} \mathrm{W} \text {, Big Beaver Pond, near } \\
\text { Tallapoosa River, Tuskegee, Alabama USA }\end{array}$ & KY091666 & Present study \\
\hline Unicaecum sp. & Trachemys scripta & Reelfoot Lake, Tennessee, USA & AY604711 & Snyder 2004 \\
\hline $\begin{array}{l}\text { Vasotrema robustum } \\
\text { Stunkard, } 1928\end{array}$ & $\begin{array}{l}\text { Apalone spinifera } \\
\text { (LeSueur) }\end{array}$ & Nishnabotna River, Floyd County, Iowa, USA & AY604706 & Snyder 2004 \\
\hline
\end{tabular}

1923, Spirorchis parvus (Stunkard, 1923), Spirorchis picta Stunkard, 1923, Spirorchis scripta Stunkard, 1923, Spirorchis minutus Byrd, 1939 and Spirorchis kirki (Platt, 1990). We also emend the diagnosis for Spirorchis and provide an updated phylogeny based on all available sequences representing members of the genus. This is the first report of a TBF from Alabama and from this turtle species as well as the first new species of TBF described from North America in 26 years, since Spirorchis kirki (see Platt 1990).

\section{MATERIALS AND METHODS}

Two chicken turtles (one juvenile [carapace $53.6 \mathrm{~mm} \times$ $44.1 \mathrm{~mm}$, plastron $47.1 \mathrm{~mm} \times 34.0 \mathrm{~mm}$ ]; one adult female [carapace $199.8 \mathrm{~mm} \times 143.2 \mathrm{~mm}$, plastron $193.0 \mathrm{~mm} \times 116.9 \mathrm{~mm}$ ]) were captured by hand from Salt Pond $\left(31^{\circ} 10^{\prime} 14^{\prime \prime} \mathrm{N} ; 86^{\circ} 32^{\prime} 18^{\prime \prime} \mathrm{W}\right.$; Yellow River, Alabama, USA) and by seine from Big Beaver Pond (32 $25^{\prime} 44^{\prime \prime N}$; 85³8'45"W; Tallapoosa River, Alabama, USA) on 5 and 17 March 2016, respectively. Seven pond sliders, Trachemys scripta (Thunberg in Schoepff), were captured by hand from earthen ponds for fish aquaculture at the EW Shell Fisheries Center $\left(32^{\circ} 38^{\prime} 53^{\prime \prime N}\right.$; $85^{\circ} 29^{\prime} 07^{\prime \prime} \mathrm{W}$; Tallapoosa River drainage, Auburn University, Auburn, Alabama, USA) on 16 January 2015. Turtles were transported alive to the laboratory in a cooler with a small portion of pond water (carried within an air conditioned vehicle cab), decapitated immediately before necropsy, and examined with the aid of $7.0 \mathrm{~g} / 1$ sodium citrate saline solution and a stereo-dissection microscope. Each host organ (brain, eye, heart, lung, spleen, liver, intestine, mesentery, kidney, rectum) was isolated in a glass container filled with saline. Portions of each organ then were excised and macerated in a petri dish while viewing under high magnification with the dissection microscope until the entire organ had been examined. The sediment from each petri dish and holding container was then examined to gather TBFs that had crawled or fallen from the excised organ/ tissue. Living flukes were pipetted from saline dishes, concentrated in a clean glass dish with saline, rinsed in saline, pipetted onto glass slides, cover-slipped (only to keep the flukes from curling; no pressure exerted on specimen by coverslip), and killed with a $2 \mathrm{~s}$ exposure to heat emitted from a butane hand lighter. After heat killing, a few drops of saline were applied to the edge of the coverslip before the coverslip was lifted carefully with fine forceps and the fluke was washed from the slide and into a clean dish of 5\% neutral buffered formalin (n.b.f.). These flukes, intended for morphology, were held in 5\% n.b.f. overnight, rinsed with distilled water, stained in Van Cleave's hematoxylin with several drops of Ehrlich's hematoxylin, dehydrated with a graded ethanol series, made basic at $70 \% \mathrm{EtOH}$ with lithium carbonate and butyl-amine, dehydrated in absolute $\mathrm{EtOH}$ and xylene, cleared with clove oil and permanently mounted in Canada balsam. Drawings were made with Leica DM2500 (Leica, Wetzler, Germany) and Leica DMR compound microscopes, each equipped with differential interference contrast optical components and a drawing tube. Measurements were obtained with a calibrated ocular micrometer (as straight-lines along the course of each duct) and are herein reported in micrometres $(\mu \mathrm{m})$ followed by their mean and number measured in parentheses. For convenient comparison, measurements of the holotype (American Museum of Natural History [AMNH] Cat. No. 128) and paratype (AMNH 130) of Spirorchis scripta are indicated in brackets (and included in the treatment of $S$. cf. scripta), e.g. "[holotype measurement, paratype measurement]," immediately following the parentheses ("n/a' indicates not available due to poor specimen quality or a damaged specimen). Turtle scientific names and taxonomic authorities follow van Dijk et al. (2014). Classification and anatomical terms for TBFs follow Roberts et al. (2016a).

Specimens intended for molecular biology comprised the anterior end of one specimen of Spirorchis cf. scripta and the posterior end of one specimen of the new species. The remainder of each of specimen (posterior end for S. cf. scripta, anterior end for new species) was deposited as a voucher (hologenophore) in the United States National Museum (USNM Cat. Nos. 1422049 and 1422046, respectively). Samples for molecular analyses were 
stored in a vial of absolute ethanol at $-20^{\circ} \mathrm{C}$. Total genomic DNA (gDNA) was extracted using the DNeasyTM Blood and Tissue Kit (Qiagen, Valencia, California, USA), except for the incubation period with proteinase-K that was extended to overnight and the final elution step wherein only $100 \mu$ of elution buffer was used to increase the final DNA concentration in the eluate. Partial 28S rDNA (domains D1-D3; 1400 bp) was amplified using the forward primer 'U178' (5'-GCA CCC GCT GAA YTT AAG-3') and the reverse primer 'L1642' (5'-CCA GCG CCATCC ATT TTC A-3') (Lockyer et al. 2003). PCR amplifications were performed using a total volume of $25 \mu$ containing approximately $2 \mu \mathrm{l}$ of DNA template, $0.4 \mu \mathrm{M}$ of each primer along with $1 \times$ buffer, $2.5 \mathrm{mM} \mathrm{MgCl}_{2}$ (New England Biolabs, Ipswich, Massachusetts, USA), $1 \mathrm{mM}$ dNTP mixture, and $0.3 \mu \mathrm{l}$ Taq polymerase ( $5 \mathrm{U} / \mu \mathrm{l})(\mathrm{New}$ England Biolabs). Thermocycling profile consisted of an initial five min at $95^{\circ} \mathrm{C}$ for denaturation, followed by 40 repeating cycles of $94^{\circ} \mathrm{C}$ for $30 \mathrm{~s}$ for denaturation, $50^{\circ} \mathrm{C}$ for $30 \mathrm{~s}$ for annealing, and $72{ }^{\circ} \mathrm{C}$ for two min for extension, followed by a final five min at $72{ }^{\circ} \mathrm{C}$ for extension. All PCR reactions were carried out in a Veriti Thermal Cycler (Applied Biosystems, Waltham, Massachusetts, USA). PCR products ( $5 \mu 1)$ were verified on a $1 \%$ agarose gel and stained with ethidium bromide. DNA Sanger sequencing was performed by Lucigen Corporation (Madison, Wisconsin, USA) using the same PCR primers.

Sequence assembling and analysis of chromatograms were conducted using BioNumerics version 7.0 (Applied Maths, Sint-Martens-Latem, Belgium). Sequences were aligned with those of other blood flukes available on GenBank. The outgroup comprised Baracktrema obamai Roberts, Platt et Bullard, 2016 (KX061500) and Unicaecum sp. (AY604711). The ingroup comprised newly-generated sequence data from Spirorchis cf. scripta (KY091666), the new species (KY091664) and Spirorchis picta (KY091665) plus six other TBFs in GenBank (Table 1). Methods for sequence alignment and phylogenetic tree construction follow Roberts et al. (2016b).

The holotype and paratypes of the new species and vouchers of the redescribed species were deposited in the United States National Museum (USNM, Washington, D.C.) and the Institute of Parasitology (IPCAS, Biology Centre of the Czech Academy of Sciences, České Budějovice, Czech Republic).

\section{RESULTS}

\section{Spirorchis MacCallum, 1918, emended}

Figs. 1-8

Diagnosis: Body dorsoventrally flattened (not cylindrical), 3-10× longer than wide, aspinous, apapillate. Oral sucker spheroid, spinous or aspinous. Ventral sucker absent. Dorsolateral and ventrolateral nerve chords present. Pharynx present, enveloping anterior extremity of oesophagus. Oesophagus sinuous, extending posteriad $<1 / 3$ of body length, ventral to anterior nerve commissure; lateral oesophageal diverticula increasing in size and number posteriad; median oesophageal diverticulum present or absent; oesophageal gland surrounding oesophagus from posterior margin of pharynx to caecal bifurcation, strongly basophilic, widest at level immediately anterior to median oesophageal diverticulum or caecal bifurcation (Figs. 5, 6). Intestine inverse U-shaped, comprising paired caeca extending 2/3-9/10 of body length directly posteriad and in parallel with body margin, terminating in posterior end of body, smooth (lacking diverticula).

Testes 4-11 in number, oblong, lobes present or absent, distributing in an intercaecal or postcaecal column, having abutting or overlapping anterior and posterior margins or relatively far separated from each other. Vas deferens extending posteriad ventral to testicular column, receiving laterally directed vasa efferentia at midline, extending posteriad from anterior testis; external seminal vesicle post-testicular, abutting posterior testis, intercaecal; internal seminal vesicle constricted medially, comprising proximal and distal swellings. Cirrus sac present, post-testicular; cirrus present.

Ovary lobed or not, intercaecal or postcaecal, post-testicular. Oviduct emerging from posterior margin of ovary, extending posteriad; oviducal seminal receptacle comprising middle portion of oviduct, at level of or posterior to genital pore. Laurer's canal intercaecal or postcaecal, post-testicular, post-ovarian, extending posteriad from oviduct at level of vitelline reservoir, opening dorsally. Vitellarium follicular, occupying space from middle region of oesophagus to distal ends of caeca; transverse vitelline duct intercaecal, post-gonadal. Ootype diminutive, post-gonadal, intercaecal, anterior to transverse vitelline duct. Mehlis' gland present or indistinct in adults. Uterus partly or wholly comprising metraterm; metraterm post-gonadal or lateral to ovary. Uterine pouch absent. Uterine egg typically observed as a single egg occupying the ootype and uterus proximal to metraterm. Common genital pore ventral, opening ventral to sinistral caecum, lacking suckers. Excretory vesicle Y-shaped; Manter's organ present or absent; excretory pore dorsal, subterminal or nearly terminal. In blood of North American chelydrids and emydids.

Differential diagnosis: Body 3-10× longer than wide, aspinous, apapillate. Ventral sucker absent. Pharynx present. Oesophagus $<1 / 3$ of body length; lateral oesophageal diverticula present; median oesophageal diverticulum present or absent. Intestine inverse U-shaped. Testes 4-11 in number, distributing in an intercaecal column. External seminal vesicle abutting posterior testis, intercaecal or postcaecal. Internal seminal vesicle constricted medially. Cirrus sac present, post-testicular. Ovary post-testicular. Oviducal seminal receptacle at level of or posterior to genital pore. Laurer's canal post-testicular, post-ovarian. Common genital pore ventral, opening ventral to sinistral caecum. Manter's organ present or absent.

Type species: Spirorchis innominatus Ward, 1921

Remarks. The correct date of publication for MacCallum's proposal of Spirorchis is 1918 (see Anonymous [1919], which confirms that MacCallum's work was printed in 1918). Previous authors (Platt 1992, 1993, 2002) have indicated that the date was 1919, but this is incorrect (Thomas R. Platt, Saint Mary'sMary's College, Notre Dame, Indiana, USA - pers. comm.).

We accept nine species of Spirorchis: S. innominatus, S. artericola, S. haematobius, S. elegans, S. parvus, S. picta, S. scripta, S. minutus, and $S$. kirki. These species can be 


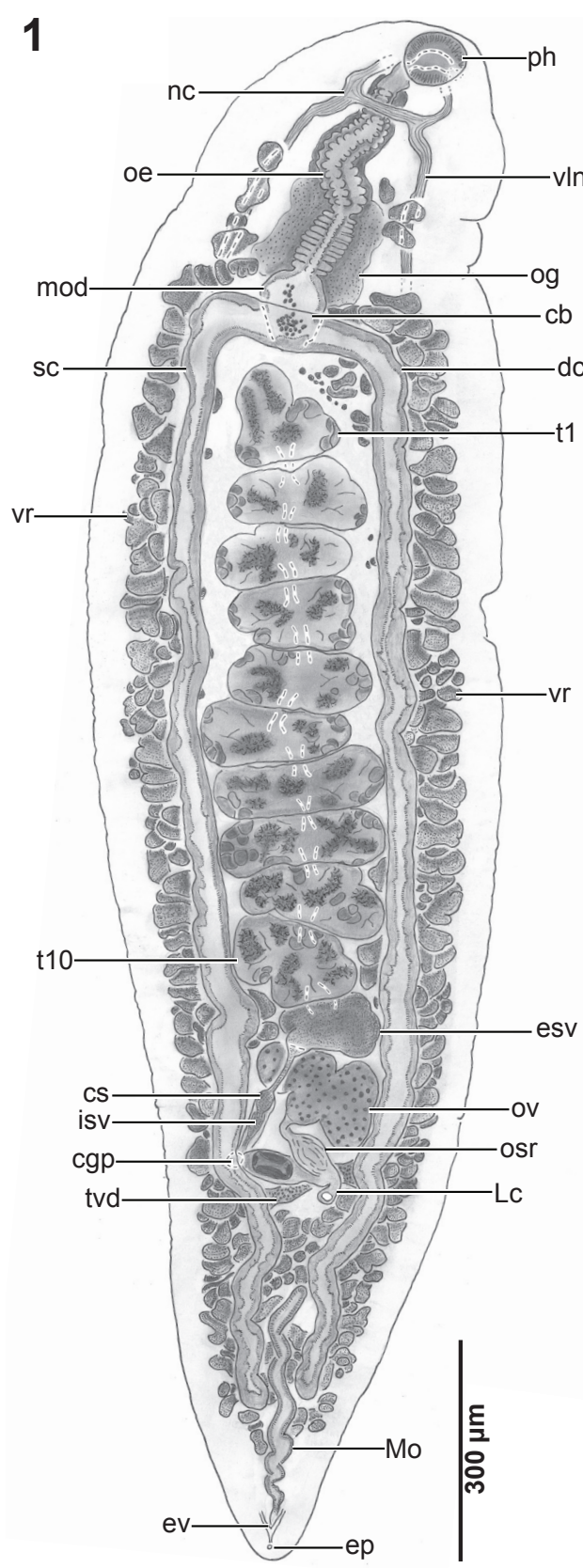

\section{2}



Figs. 1, 2. Spirorchis cf. scripta from the lung of Deirochelys reticularia (Latreille in Sonnini et Latreille) (Testudines: Emydidae) from Big Beaver Pond, Tallapoosa River, near Tuskegee, Alabama, USA. Fig. 1. Body of voucher (USNM Cat. No. 1422047), dorsal view. Fig. 2. Genitalia of voucher (USNM Cat. No. 1422047), dorsal view. Abbreviations: cb - caecal bifurcation; cgp - common genital pore; ci - cirrus; cs - cirrus sac; dc - dextral caecum; egg - uterine egg; ep - excretory pore; esv - external seminal vesicle; ev - excretory vesicle; isv - internal seminal vesicle; Lc - Laurer's canal; lvd - lateral vitelline collection duct; Mo - Manter's organ; mod - median oesophageal diverticulum; nc - nerve commissure; od - oviduct; oe - oesophagus; og - oesophageal gland; osr - oviducal seminal receptacle; ov - ovary; ph - pharynx; sc - sinistral caecum; t1 - anterior testis; t8 - testis no. 8; t9 - testis no. 9; t10 - posterior-most testis; tvd - transverse vitelline collection duct; vd - vas deferens; ve - vasa efferentia; vln - ventrolateral nerve chords; vr - vitellarium; vt - vitelline duct.

coarsely grouped based upon features of the caeca, gonads and genitalia: S. scripta and S. elegans have a testicular column that nearly abuts the caecal bifurcation and caeca that extend posteriad far beyond the genitalia; S. innominatus and $S$. artericola have a testicular column that nearly abuts the caecal bifurcation and caeca that extend posteriad only slightly beyond the genitalia; and the remaining species have a testicular column that is markedly posterior to the caecal bifurcation (S. haematobius, S. picta, S. par- vus, $S$. minutus) or that is wholly post-caecal (S. kirki) plus caeca that do not extend posteriad far beyond the genitalia (Ward 1921, Stunkard 1922, 1923, Price 1934, Byrd 1939, Platt 1990, 1992).

Spirorchis most closely resembles Spirhapalum Ejsmont, 1927, Plasmiorchis Mehra, 1934 and Carretacola Manter et Larson, 1950 by having multiple testes typically distributing in an intercaecal column. Spirorchis, Spirhapalum and Plasmiorchis are further similar to each 
3



4

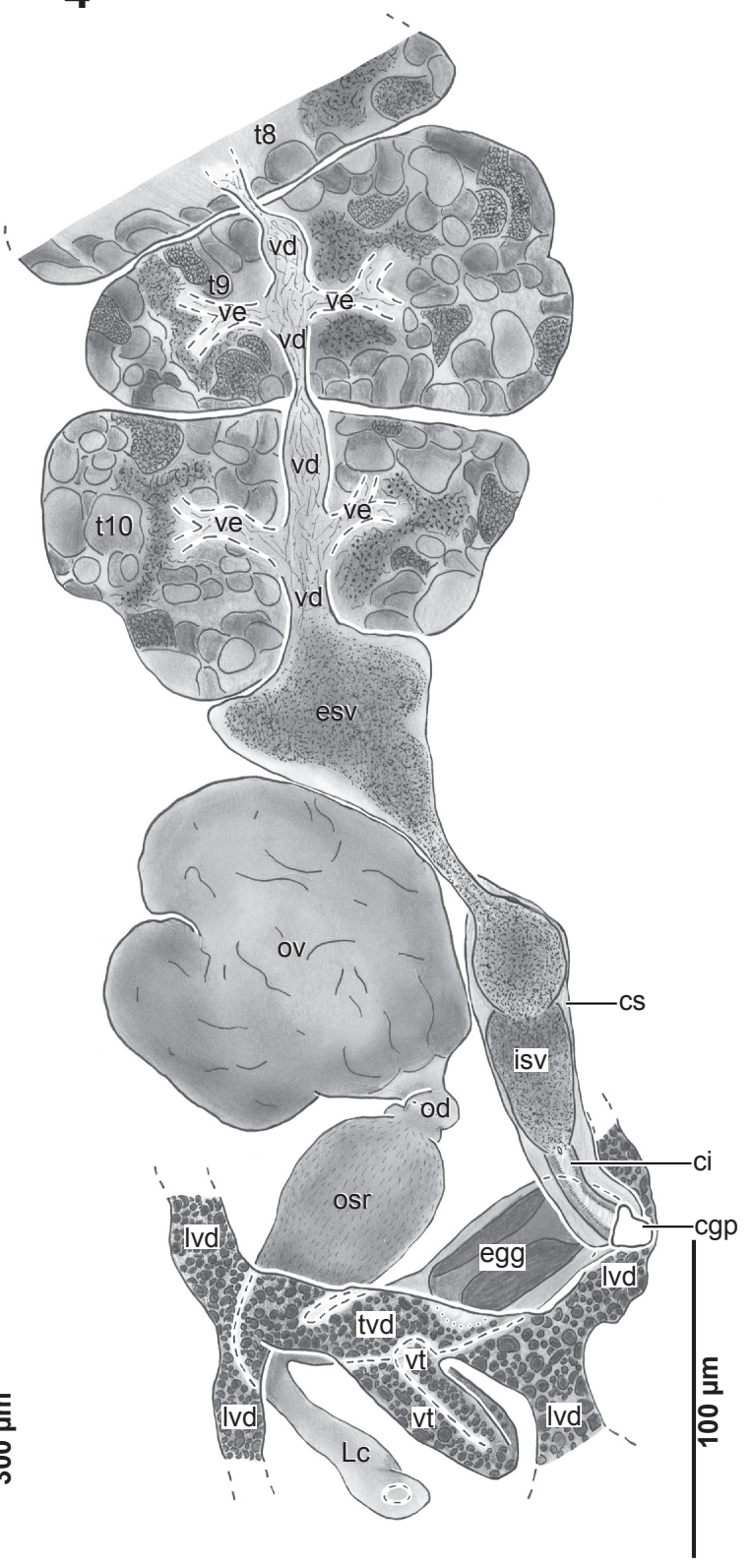

Figs. 3, 4. Spirorchis cf. scripta from the lung of Deirochelys reticularia (Latreille in Sonnini et Latreille) from Big Beaver Pond, Tallapoosa River, near Tuskegee, Alabama, USA. Fig. 3. Voucher (USNM Cat. No. 1422048), ventral view. Fig. 4. Genitalia of voucher (USNM Cat. No. 1422048), ventral view. Abbreviations: cgp - common genital pore; ci - cirrus; cs - cirrus sac; ct - caecal terminus; $\mathrm{dc}$ - dextral caecum; egg - uterine egg; ep - excretory pore; esv - external seminal vesicle; ev - excretory vesicle; isv - internal seminal vesicle; Lc - Laurer's canal; lvd - lateral vitelline collection duct; Mo - Manter's organ; mod - median oesophageal diverticulum; nc - nerve commissure; od - oviduct; oe - oesophagus; og - oesophageal gland; os - oral sucker; osr - oviducal seminal receptacle; ov - ovary; ph - pharynx; sc - sinistral caecum; t1- anterior testis; $\mathrm{t} 8$ - testis no. 8 ; $\mathrm{t} 9$ - testis no. 9; t10 - posterior-most testis; tvd - transverse vitelline collection duct; vd - vas deferens; ve - vasa efferentia; vln - ventrolateral nerve chords; vr - vitellarium; $\mathrm{vt}$ - vitelline duct.

other and unique among other TBFs by having lateral oesophageal diverticula and a median oesophageal diverticulum (Ward 1921, Stunkard 1923, Ejsmont 1927, Mehra 1934, 1939, Sinha 1934, Gupta and Mehrotra 1975, Platt 1993, 2002, Tkach et al. 2009). Spirorchis differs from Carretacola by lacking a ventral sucker and by having post-testicular female genitalia and a post-testicular genital pore. Carretacola has a ventral sucker, pre-testicular ovary and pre-gonadal common genital pore. Spirorchis differs from Plasmiorchis and Spirhapalum by lacking a ventral sucker. In addition, it differs from Spirhapalum by lacking a post-ovarian testis and from Plasmiorchis by having more-or-less straight caeca that do not turn anteriad.

The diagnosis for Spirorchis herein is emended to include the presence of oral sucker spines, a pharynx, lateral oesophageal diverticula ('plicate organ'), and a median oesophageal diverticulum ('oeseophageal pouch'). Regarding the spines, previous authors have treated Spirorchis as comprising species that are aspinous (MacCallum 1918, Ward 1921, Stunkard 1922, Stunkard 1923, Platt 1993, 

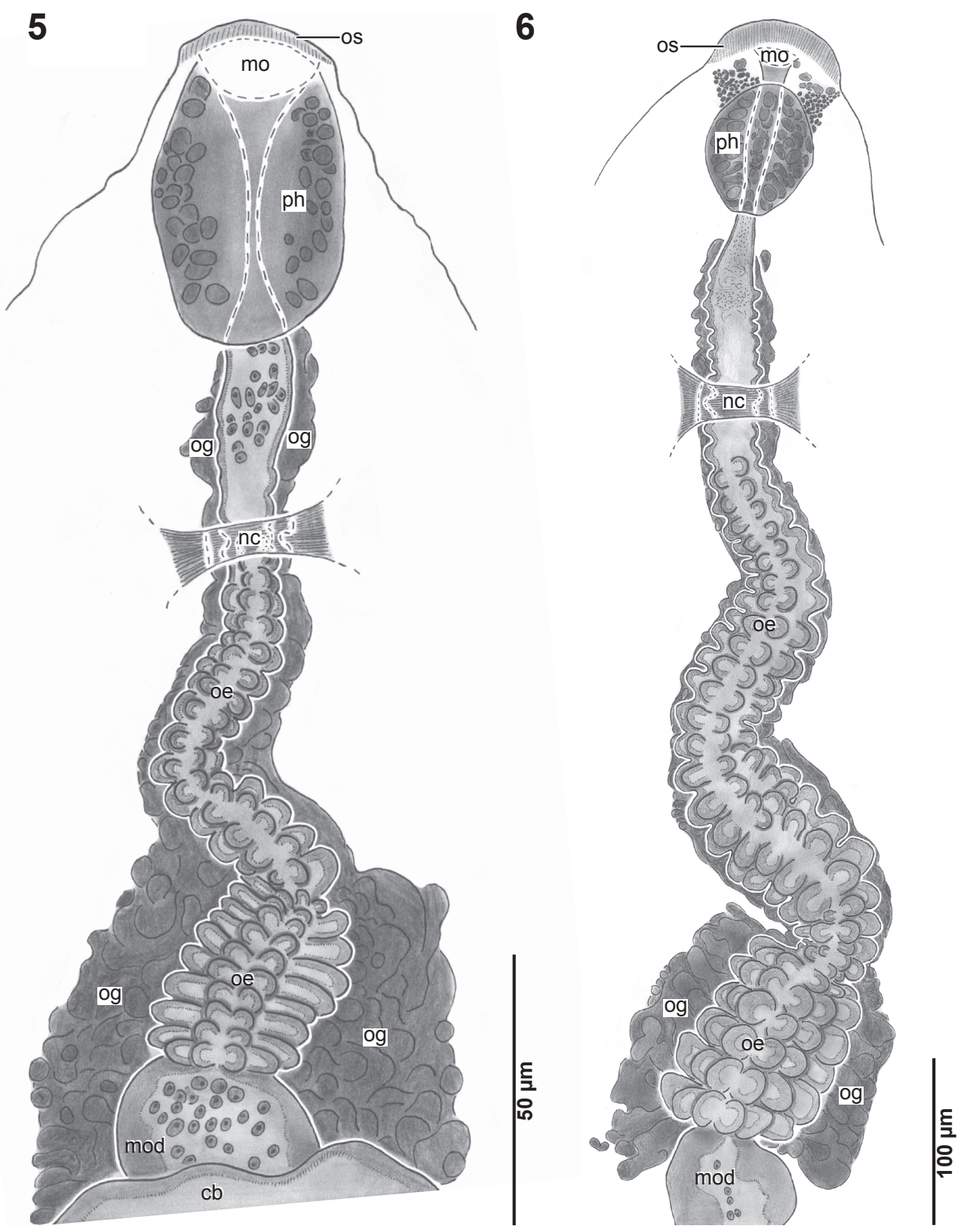

Figs. 5, 6. Oesophagus, lateral oesophageal diverticula and oesophageal gland characteristic of Spirorchis MacCallum, 1918. Fig. 5. Spirorchis scripta Stunkard, 1923 from mesenteric vessels of Trachemys scripta (Thunberg in Schoepff) from Neuse River, Raleigh, North Carolina, USA. Oesophagus of paratype (AMNH 130), dorsal view. Fig. 6. Spirorchis collinsi Roberts et Bullard, sp. n. from the kidney blood vessels of Deirochelys reticularia (Latreille in Sonnini et Latreille) from Big Beaver Pond, Tallapoosa River, near Tuskegee, Alabama, USA. Oesophagus of holotype (USNM Cat. No. 1422045), dorsal view. Abbreviations: cb - caecal bifurcation; mo - mouth; mod - median oesophageal diverticulum; nc - nerve commissure; oe - oesophagus; og - oesophageal gland; os - oral sucker; ph - pharynx.

2002). We confirmed the lack of tegumental body spines in museum materials and newly collected specimens of various Spirorchis spp., but in some well-prepared specimens, i.e. Spirorchis scripta and Spirorchis sp. (J.R.R. and S.A.B. - unpubl. data), we observed minute $(<5 \mu \mathrm{m}$ in total length), putative spines on the surface of the oral sucker. Although spinous anterior suckers are well-documented among fish blood flukes (Aporocotylidae) (Bullard et al. 2008, McVay et al. 2011, Bullard 2012, 2013, Truong and Bullard 2013), this is the first report of spines associated with the oral sucker of a TBF. Although materials at our disposal herein precluded an ultrastructural study of these minute spines, a follow-up study treating them is planned once additional specimens have been collected and prepared.

Regarding the pharynx, like Baracktrema Roberts, Platt et Bullard, 2016, Unicaecum and Coeuritrema Mehra, 1933 (see Roberts et al. 2016a,b), a pharynx is present in Spirorchis spp. MacCallum (1918) diagnosed Spirorchis as having a pharynx but mislabelled it in the description of S. innominatus as the nerve commissure (Stunkard 1923). Further, we speculate that the pharynx was previously interpreted by some workers as part of the oral sucker, as it is dorsal to the mouth. Regarding the lateral oesophageal 


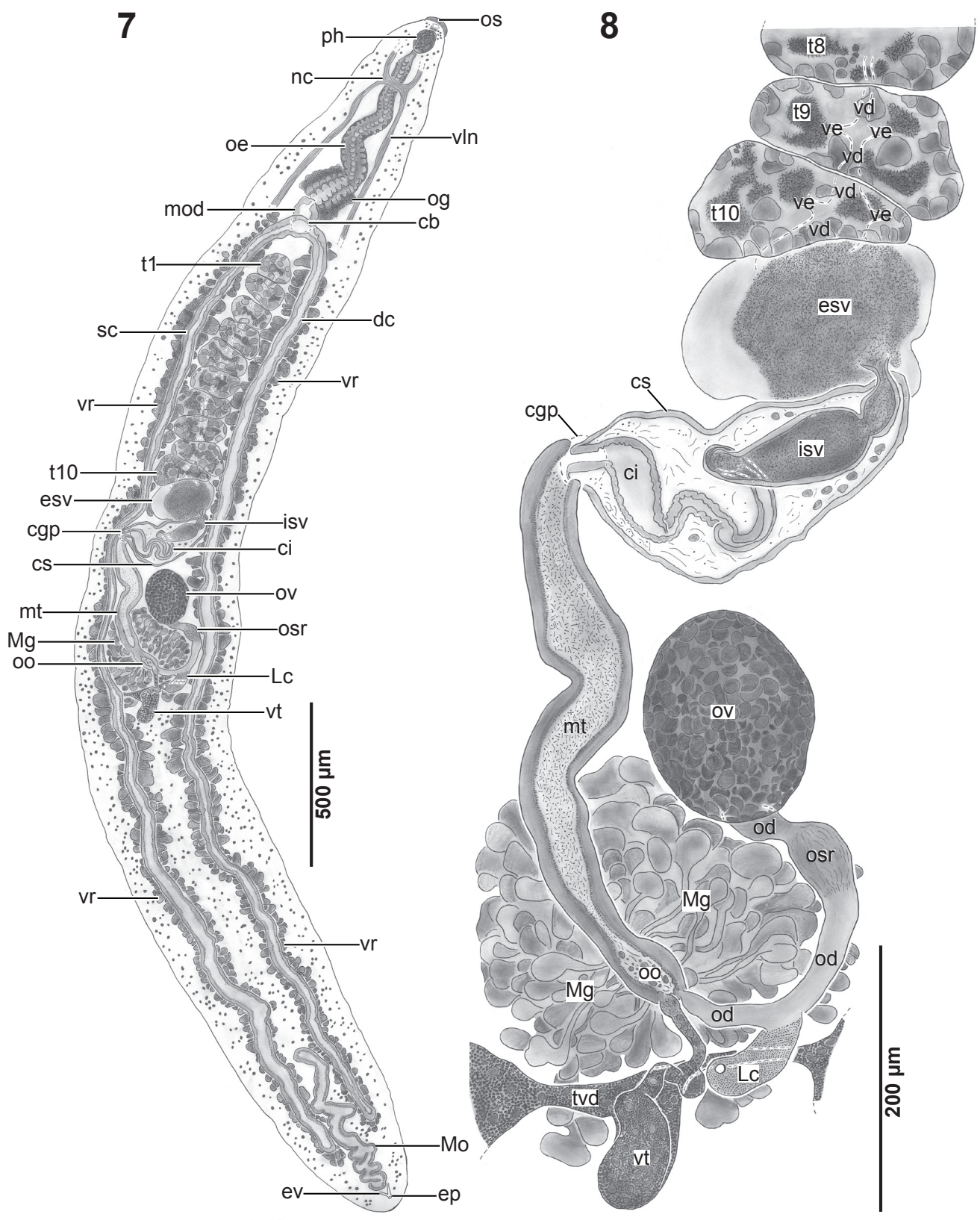

Figs. 7, 8. Spirorchis collinsi Roberts et Bullard, sp. n. from the kidney blood vessels of Deirochelys reticularia (Latreille in Sonnini et Latreille) from Big Beaver Pond, Tallapoosa River, near Tuskegee, Alabama, USA. Fig. 7. Body of holotype (USNM Cat. No. 1422045), dorsal view. Fig. 8. Genitalia of holotype (USNM Cat. No. 1422045), dorsal view. Abbreviations: cb - caecal bifurcation; cgp - common genital pore; ci - cirrus; cs - cirrus sac; dc - dextral caecum; ep - excretory pore; esv - external seminal vesicle; ev - excretory vesicle; isv - internal seminal vesicle; Lc - Laurer's canal; Mg - Mehlis' gland; Mo - Manter's organ; mod - median oesophageal diverticulum; $\mathrm{mt}$ - metraterm; nc - nerve commissure; od - oviduct; oe - oesophagus; og - oesophageal gland; oo - ootype; os - oral sucker; osr - oviducal seminal receptacle; ov - ovary; ph - pharynx; sc - sinistral caecum; t1- anterior testis; t8 - testis no. 8; t9 - testis no. 9; t10 - posterior-most testis; tvd - transverse vitelline collection duct; vd - vas deferens; ve - vasa efferentia; vln - ventrolateral nerve chords; vr - vitellarium; vt - vitelline duct.

diverticula, species of Spirorchis, Spirhapalum and Plasmiorchis (see Platt 2002) have an oesophagus with lateral diverticula (oesophageal lumen extending into each diverticulum) that become longer, more numerous and more dense posteriad (Figs. 5, 6). These diverticula have been referred to variously but most commonly as comprising a plicate organ because they appear pleated (Ward 1921, Mehra 1934, Platt 1992, 1993, 2002).

The association of the oesophageal gland and lateral oesophageal diverticula has perhaps caused some confusion.
Based on the museum specimens we examined (Table 2), it seems likely that Stunkard (1923) mistook the 'beaded appearance' of the lateral oesophageal diverticula for an oesophageal gland, and, likewise, we suspect that Mehra's (1934) 'plicated lumen' refers to the lateral oesophageal diverticula. Apparently, Rohde et al. (1968) mistook the lateral oesophageal diverticula as latitudinal muscle striation. Regarding the median oesophageal diverticulum, Ward (1921) first described this oesophageal outpocketing as a 'median diverticulum'. Noteworthy also is that the same 
Table 2. Specimens of turtle blood flukes examined in the present study.

\begin{tabular}{|c|c|c|c|c|c|c|c|c|}
\hline $\begin{array}{l}\text { Turtle blood } \\
\text { fluke }\end{array}$ & Slide label & Accession No. & $\begin{array}{l}\text { No. } \\
\text { slides }\end{array}$ & Specimen & Host & Locality & Notes & Reference \\
\hline $\begin{array}{l}\text { Spirorchis } \\
\text { artericola (Ward, } \\
1921)\end{array}$ & $\begin{array}{l}\text { Proparorchis } \\
\text { artericola }\end{array}$ & USNM 1350610 & 5 & $\begin{array}{l}\text { holotype; para- } \\
\text { types (4) }\end{array}$ & $\begin{array}{l}\text { Trachemys scripta } \\
\text { (Thunberg in } \\
\text { Schoepff) (labeled } \\
\text { Pseudemys scripta) }\end{array}$ & $\begin{array}{l}\text { Illinois River, } \\
\text { Havana, Illinois, } \\
\text { USA }\end{array}$ & & Ward 1921 \\
\hline $\begin{array}{l}\text { Spirorchis } \\
\text { innominatus } \\
\text { Ward, 1921 (type } \\
\text { species) }\end{array}$ & $\begin{array}{l}\text { Spirorchis } \\
\text { eustreptos }\end{array}$ & USNM 1337308 & 1 & $\begin{array}{l}\text { holotype; } \\
\text { paratypes (2); } \\
\text { Telorchis sp. (3) }\end{array}$ & $\begin{array}{l}\text { Glyptemys insculp- } \\
\text { ta (Le Conte) (la- } \\
\text { beled as Chelopus } \\
\text { insculptus) }\end{array}$ & $\begin{array}{l}\text { origin not spec- } \\
\text { ified, New York } \\
\text { Aquarium, New } \\
\text { York, USA }\end{array}$ & $\begin{array}{l}\text { holotype } \\
\text { circled, labeled } \\
\text { as "TYPE" }\end{array}$ & $\begin{array}{l}\text { MacCallum } \\
1918,1926, \\
\text { Ward } 1921\end{array}$ \\
\hline \multirow[t]{2}{*}{$\begin{array}{l}\text { Spirorchis } \\
\text { haematobius } \\
\text { (Stunkard, 1922) }\end{array}$} & $\begin{array}{l}\text { Henotosoma } \\
\text { haematobium }\end{array}$ & AMNH 126 & 1 & holotype & $\begin{array}{l}\text { Chelydra serpenti- } \\
\text { na (Linnaeus) }\end{array}$ & $\begin{array}{l}\text { Kankakee River, } \\
\text { North Judson, } \\
\text { Indiana, USA }\end{array}$ & $\begin{array}{l}\text { misspelled as } \\
\text { Henostoma in } \\
\text { AMNH database }\end{array}$ & Stunkard 1922 \\
\hline & & AMNH 1264 & 10 & $\begin{array}{l}\text { paratypes (9); } \\
\text { tissue serially } \\
\text { sectioned }\end{array}$ & & $\begin{array}{l}\text { Neuse River, } \\
\text { Raleigh, North } \\
\text { Carolina, USA }\end{array}$ & $\begin{array}{l}1 \text { intact speci- } \\
\text { men, } 8 \text { partial } \\
\text { specimens }\end{array}$ & \\
\hline \multirow[t]{2}{*}{$\begin{array}{l}\text { Spirorchis ele- } \\
\text { gans Stunkard, } \\
1923\end{array}$} & $\begin{array}{l}\text { Spirorchis } \\
\text { elegans }\end{array}$ & AMNH 134 & 1 & holotype & $\begin{array}{l}\text { Trachemys scripta } \\
\text { (labeled Pseude- } \\
\text { mys elegans) }\end{array}$ & $\begin{array}{l}\text { Illinois River, } \\
\text { Havana, Illinois, } \\
\text { USA }\end{array}$ & & Stunkard 1923 \\
\hline & & AMNH 1516 & 1 & paratype & & & & \\
\hline $\begin{array}{l}\text { Spirorchis parvus } \\
\text { (Stunkard, 1923) }\end{array}$ & $\begin{array}{l}\text { Haematotrema } \\
\text { parvum }\end{array}$ & AMNH 133 & 1 & holotype & $\begin{array}{l}\text { Chrysemys picta } \\
\text { (Schneider) }\end{array}$ & $\begin{array}{l}\text { Hudson River, } \\
\text { Cold Spring, } \\
\text { New York, USA }\end{array}$ & & Stunkard 1923 \\
\hline \multirow[t]{2}{*}{$\begin{array}{l}\text { Spirorchis picta } \\
\text { Stunkard, } 1923\end{array}$} & Spirorchis picta & AMNH 131 & 1 & holotype & Chrysemys picta & $\begin{array}{l}\text { New York City, } \\
\text { New York, USA }\end{array}$ & & Stunkard 1923 \\
\hline & & AMNH 1515 & 1 & paratype & & & & \\
\hline \multirow[t]{2}{*}{$\begin{array}{l}\text { Spirorchis } \\
\text { scripta } \text { Stunkard, } \\
1923\end{array}$} & $\begin{array}{l}\text { Spirorchis } \\
\text { scripta }\end{array}$ & AMNH 128 & 1 & holotype & $\begin{array}{l}\text { Trachemys scripta } \\
\text { (labeled Pseude- } \\
\text { mys scripta) }\end{array}$ & $\begin{array}{l}\text { Neuse River, } \\
\text { Raleigh, North } \\
\text { Carolina, USA }\end{array}$ & $\begin{array}{l}\text { specimen dam- } \\
\text { aged }\end{array}$ & Stunkard 1923 \\
\hline & & AMNH 130 & 1 & paratype & & & & \\
\hline $\begin{array}{l}\text { Spirorchis minu- } \\
\text { tus } \text { Byrd, } 1939\end{array}$ & $\begin{array}{l}\text { Spirorchis } \\
\text { minutum }\end{array}$ & USNM 1321965 & 1 & holotype & $\begin{array}{l}\text { Chelydra serpen- } \\
\text { tina }\end{array}$ & $\begin{array}{l}\text { Reelfoot Lake, } \\
\text { Tennessee, USA }\end{array}$ & $\begin{array}{l}\text { specimen dam- } \\
\text { aged }\end{array}$ & Byrd 1939 \\
\hline $\begin{array}{l}\text { Spirorchis kirki } \\
\text { (Platt, 1990) }\end{array}$ & $\begin{array}{l}\text { Aphanospiror- } \\
\text { chis kirki }\end{array}$ & $\begin{array}{l}\text { Thomas R. } \\
\text { Platt's collection }\end{array}$ & 4 & paratypes (4) & $\begin{array}{l}\text { Chrysemys picta } \\
\text { marginata (Agas- } \\
\text { siz) }\end{array}$ & $\begin{array}{l}\text { St. Joseph River, } \\
\text { Center Town- } \\
\text { ship, St. Joseph } \\
\text { County, Indiana, } \\
\text { USA }\end{array}$ & $\begin{array}{l}\text { specimens part } \\
\text { of } * \text { TRP's } \\
\text { personal collec- } \\
\text { tion, (donated to } \\
\text { SAB) }\end{array}$ & Platt 1990 \\
\hline
\end{tabular}

* Thomas R. Platt, Professor Emeritus, Saint Mary’s College, Notre Dame, Indiana, USA.

structure has been referred to as 'median pocket' (Stunkard 1923), 'petite poche' (Ejsmont 1927), 'oesophageal vesicle' (Mehra 1934, Gupta and Mehrotra 1975), 'pocket-like structure' (Sinha 1934), and 'median oesophageal pouch' (Platt 1992, 1993, 2002). We suggest the term 'median oesophageal diverticulum' because Ward's (1921) description was the first to identify and name the structure and because we suspect that this feature may be homologous with the lateral oesophageal diverticula.

Interpreting the distal portion of the female genitalia, i.e. differentiating the ootype, thin-walled proximal portion of the uterine tract and distal metraterm, is challenging in gravid specimens because the presence of the large egg blurs definition of these structures in whole-mounted specimens viewed with light microscopy. This is taxonomically problematic because gravid adults of Spirorchis spp. are common (J.R.R. - pers. obs.). MacCallum (1918) did not discern an ootype or uterus in the gravid holotype of the type species, S. innominatus. Ward (1921) studied gravid specimens of $S$. artericola and stated that, "the egg lies really in the ootype and a true uterus is lacking." Later, Stunkard (1923), Byrd (1939) and Ulmer (1959) histologically differentiated the proximal portion of the uterus from the metraterm in species of Spirorchis. These structures probably do comprise a functional 'egg chamber' (Roberts et al. 2016b) as in S. elegans and S. scripta. However, $S$. picta and the new species described herein have a uterus comprised wholly of a metraterm immediately distal to the ootype.

\section{Spirorchis cf. scripta}

Figs. $1-5,9$

Description of adult (based on light microscopy of five adult specimens): Body 1260-2090 (1724; 5) [n/a, 1150 ] long or $3.3-4.4 \times(3.8 \times ; 5)[\mathrm{n} / \mathrm{a}, 4.8]$ longer than wide, $360-500(404 ; 5)[255,225]$ wide or $19-30 \%(24 \%$; 5) [n/a, 20\%] of body length at level of caecal bifurcation, $380-560(448 ; 5)[280,240]$ wide or $23-30 \%(26 \% ; 5)$ [n/a, 21\%] of body length at level of middle testis (typically maximum body width), 200-230 $(214 ; 5)[150,110]$ wide or $10-17 \%(13 \% ; 5)[\mathrm{n} / \mathrm{a}, 10 \%]$ of body length at level of caecal terminus (Figs. 1, 3).

Oral sucker $25-45(39 ; 5)$ [n/a, 30] long or $2-3 \%(2 \%$; 5) $[\mathrm{n} / \mathrm{a}, 3 \%]$ of body length, $50-65(56 ; 5)[\mathrm{n} / \mathrm{a}, 60]$ wide or $10-18 \%(14 \% ; 4)[\mathrm{n} / \mathrm{a}, 27 \%]$ of body width at level of caecal bifurcation (Figs. 1, 3). Nerve commissure 140-188 $(161 ; 4)[\mathrm{n} / \mathrm{a}, 120]$ or $7-12 \%(9 \% ; 4)[\mathrm{n} / \mathrm{a}, 10 \%]$ of body length from anterior body end. Pharynx 60-90 $(77 ; 4)[\mathrm{n} / \mathrm{a}$, 53] long or $15-20 \%(16 \%$; 4) [n/a, 18\%] of oesophagus length, $55-70(61 ; 5)[\mathrm{n} / \mathrm{a}, 48]$ wide or $2.8-4.8 \times(3.7 \times ; 5)$ $[\mathrm{n} / \mathrm{a}, 3.7]$ oesophagus width immediately posterior to pharynx, $1.0-1.4 \times(1.2 \times ; 4)[\mathrm{n} / \mathrm{a}, 1.1]$ longer than wide (Figs. $1,3)$. Oesophagus extending posteriad 250-565 $(427 ; 5)$ [n/a, 301] long or $20-30 \%(25 \% ; 5)$ [n/a, $26 \%$ ] of body 


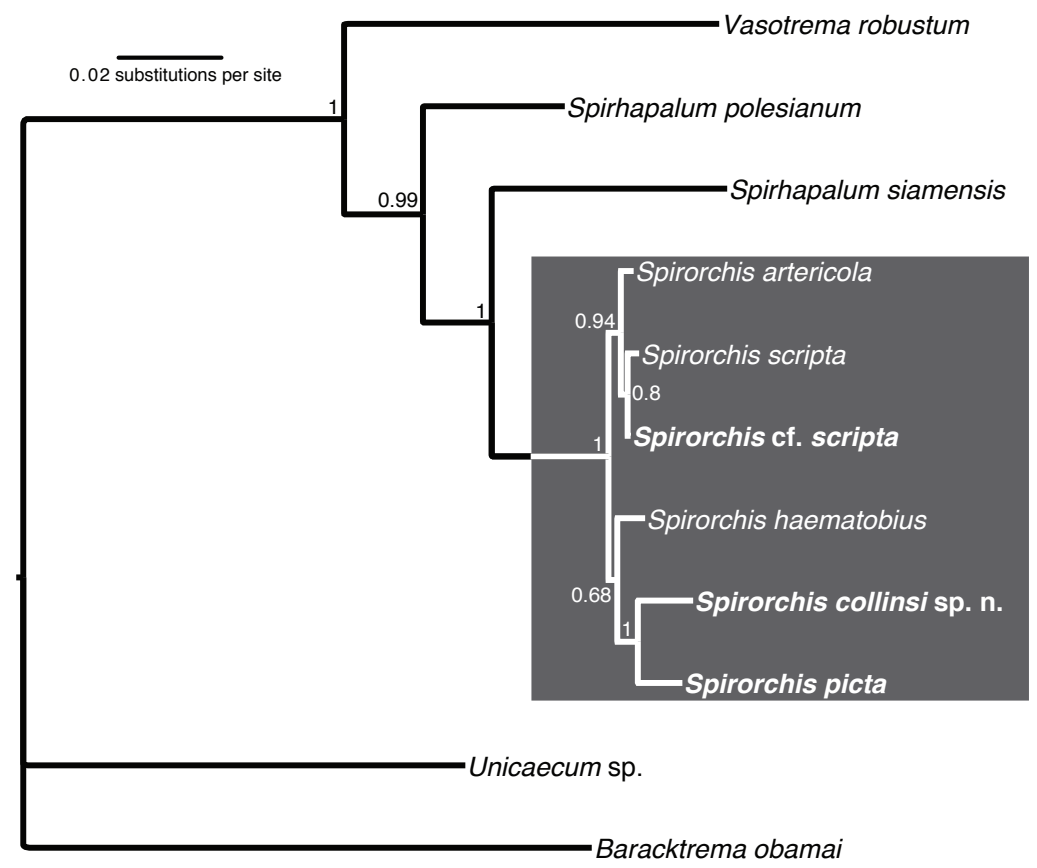

Fig. 9. Phylogenetic relationships of blood flukes reconstructed by Bayesian interference and based on partial D1-D3 domains of 28S from $11 \mathrm{TBF}$ taxa. Numbers aside tree nodes indicate posterior probability.

length from mouth to posterior margin of median oesophageal diverticulum, 13-25 $(17 ; 5)$ [n/a, 13] wide posterior to pharynx, with wall $10-15(12 ; 5)[\mathrm{n} / \mathrm{a}, 10]$ thick, 35-50 $(40 ; 5)[\mathrm{n} / \mathrm{a}, 15]$ wide at oesophagus median or $8-13 \%$ $(10 \% ; 5)[\mathrm{n} / \mathrm{a}, 7 \%]$ of body width at level of caecal bifurcation, with wall 15-25 $(19 ; 5)$ [n/a, 12] thick, 45-65 (55; 5) $[\mathrm{n} / \mathrm{a}, 35]$ wide anterior to median oesophageal diverticulum or $12-15 \%(14 \% ; 5)[\mathrm{n} / \mathrm{a}, 7 \%$ ] of body width at level of caecal bifurcation, with wall 35-45 $(40 ; 5)$ [n/a, 30] thick; median oesophageal diverticulum 200-475 $(344 ; 5)$ [n/a, 250] or $16-25 \%(20 \% ; 5)$ [n/a, 22\%] of body length from anterior body end, $75-130(109 ; 5)[100,68]$ long or $21-30 \%(26 \% ; 5)[\mathrm{n} / \mathrm{a}, 23 \%$ ] of oesophagus length, 58-90 $(78 ; 5)[35,50]$ wide or $13-23 \%(20 \% ; 5)[14 \%, 22 \%]$ of body width at level of caecal bifurcation; oesophageal gland $173-410(271 ; 5)$ [n/a, 195] long or $12-22 \%(15 \%$; 5) $[\mathrm{n} / \mathrm{a}, 17 \%$ ] of body length, 100-135 $(117 ; 5)$ [n/a, 105] wide or $26-35 \%(29 \% ; 5)$ [n/a, $47 \%$ ] of body width at level of caecal bifurcation (Figs. 1, 3).

Intestinal bifurcation $230-525(389 ; 5)[\mathrm{n} / \mathrm{a}, 280]$ from anterior body end or $18-28 \%(22 \% ; 5)[\mathrm{n} / \mathrm{a}, 24 \%$ ] of body length, dorsal to median oesophageal diverticulum (Figs. 1, 3); sinistral caecum 850-1 $530(1180 ; 5)$ [1 085, 775] long or $60-73 \%(68 \%$; 5) [n/a, 67\%] of body length, 30-53 (43; 5) $[25,25]$ wide or $8-15 \%(11 \% ; 5)[10 \%, 11 \%]$ of body width at level of caecal bifurcation, $28-50(34 ; 5)[20,18]$ wide or $7-9 \%(8 \% ; 5)[7 \%, 8 \%]$ of body width at level of middle testis, $18-40(30 ; 3)[20,18]$ wide or $9-20 \%(14 \%$; 5) $[13 \%, 16 \%]$ of body width at level of caecal terminus; dextral caecum 850-1 $470(1138 ; 5)[1095,745]$ long or $60-72 \%(66 \% ; 5)[\mathrm{n} / \mathrm{a}, 67 \%$ ] of body length, 25-45 (36; 5) $[25,25]$ wide or $7-13 \%(9 \% ; 5)[10 \%, 11 \%]$ of body width at level of caecal bifurcation, $28-45(35 ; 5)[20,20]$ wide or $7-8 \%(8 \% ; 5)[7 \%, 8 \%]$ of body width at level of middle testis, $25-35(30 ; 5)[20,18]$ wide or $12-18 \%$ $(14 \% ; 5)[13 \%, 16 \%]$ of body width at level of caecal terminus; post-caecal distance $115-235(185 ; 5)[145,125]$ or $9-12 \%(11 \% ; 5)[\mathrm{n} / \mathrm{a}, 11 \%]$ of body length.

Testes $10(5)[10,10]$ in number, having abutting or overlapping anterior and posterior margins; testicular column $23-90(46 ; 5)[35,8]$ or $1-5 \%(3 \% ; 5)[\mathrm{n} / \mathrm{a}, 1 \%]$ of body length from caecal bifurcation, 428-880 $(632 ; 5)$ $[630,425]$ long or $31-42 \%(36 \% ; 5)$ [n/a, 37\%] of body length; anterior testis (t1) 48-135 $(83 ; 5)[85,48]$ long or $4-6 \%(5 \% ; 5)[\mathrm{n} / \mathrm{a}, 4 \%$ ] of body length, $88-135(113 ; 5)$ $[85,65]$ wide or $20-30 \%(25 \% ; 5)[30 \%, 27 \%]$ of body width at level of middle testis, $1.0-2.0 \times(1.5 \times ; 5)[1.0,1.4]$ wider than long, $8-35(25 ; 5)[15,5]$ from sinistral caecum, $8-50(32 ; 5)[15,8]$ from dextral caecum; middle testis (t5) $45-85(63 ; 5)[60,50]$ long or $3-4 \%(4 \% ; 5)[\mathrm{n} / \mathrm{a}, 4 \%]$ of body length, 88-200 $(138 ; 5)[120,88]$ wide or $23-36 \%$ $(30 \% ; 5)[43 \%, 37 \%]$ of body width at level of middle testis, $1.7-3.3 \times(2.2 \times ; 5)[2.0,1.8]$ wider than long, 8-30 (20; 5) [abutting, abutting] from sinistral caecum, 5-35 $(19 ; 5)$ [abutting, abutting] from dextral caecum; posterior-most testis $325-745(577 ; 5)[565,375]$ or $17-43 \%(34 \% ; 5)$ [n/a, 33\%] of body length from posterior body end, 34-120 $(79 ; 5)[75,53]$ long or $3-6 \%(4 \% ; 5)[\mathrm{n} / \mathrm{a}, 5 \%]$ of body length, $68-170(129 ; 5)[100,100]$ wide or $18-36 \%(29 \%$; 5) $[36 \%, 42 \%]$ of body width at level of middle testis, $1.4-2.0 \times(1.7 \times ; 5)[1.3,1.9]$ wider than long, abutting or 13-15 $(14 ; 2)$ [abutting, abutting] from sinistral caecum, abutting or $18-35(28 ; 3)$ [abutting, abutting] from dextral caecum (Figs. 1, 3).

Vas deferens 525-750 (605; 3) [540, 413] long or $28-37 \%(33 \% ; 3)$ [n/a, 36\%] of body length, 10-13 (11; 4) $[13,13]$ wide, ventral to testicular column, laterally expanding before joining external seminal vesicle posterior 
to posterior testis (Figs. 2, 4); external seminal vesicle $88-115(101 ; 5)[103,83]$ long or $4-8 \%(6 \% ; 5)[\mathrm{n} / \mathrm{a}, 7 \%]$ of body length, 65-133 $(106 ; 5)[78,93]$ wide or $15-28 \%$ $(24 \% ; 5)[28 \%, 39 \%]$ of body width at level of middle testis, $0.7-1.4 \times(1.0 \times ; 5)[1.3,0.9]$ longer than wide (Figs. 2, $4)$; internal seminal vesicle $50-80(69 ; 5)[60,43]$ long or $3-5 \%(4 \% ; 5)[\mathrm{n} / \mathrm{a}, 4 \%$ ] of body length, 20-28 (24; 5) [18, $15]$ maximum width or $80-100 \%(91 \%$; 5) [60\%, 43\%] of cirrus sac width, $1.8-3.5 \times(2.9 \times ; 5)[3.3,2.9]$ longer than wide (Figs. 2, 4); proximal portion of internal seminal vesicle $18-30(25 ; 5)[20,20]$ long or $28-41 \%(36 \% ; 5)[33 \%$, $47 \%$ ] of total internal seminal vesicle length, 20-28 (23; 5) $[18,15]$ wide; distal portion of internal seminal vesicle $30-52(44 ; 5)[40,23]$ long or $59-72 \%(64 \% ; 5)[67 \%$, $53 \%$ ] of total internal seminal vesicle length, 20-28 (24; 5) $[13,13]$ wide. Cirrus sac $75-115(95 ; 5)[85,68]$ long or $5-6 \%(6 \% ; 5)[\mathrm{n} / \mathrm{a}, 6 \%$ ] of body length, $25-30(27 ; 5)$ $[30,35]$ wide or $4-7 \%(6 \% ; 5)[11 \%, 15 \%]$ of body width at level of middle testis; cirrus straight, 20-35 $(28 ; 5)$ [n/a, 20] long or $1-2 \%(2 \% ; 5)$ [n/a, $2 \%$ ] of body length, $5-13$ $(9 ; 5)[\mathrm{n} / \mathrm{a}, 8]$ wide or $1-3 \%(2 \% ; 5)[\mathrm{n} / \mathrm{a}, 3 \%$ of maximum body width.

Ovary lobed, 3-6 lobes $(5 ; 5)[4,6]$, intercaecal, posterior to external seminal vesicle, lateral to cirrus sac, $98-120$ $(106 ; 5)[115,100]$ long or $5-8 \%(6 \% ; 5)[\mathrm{n} / \mathrm{a}, 9 \%]$ of body length, 93-180 $(126 ; 5)[93,88]$ wide or $24-32 \%$ $(28 \% ; 5)[33 \%, 37 \%]$ of body width at level of middle testis, $0.9-1.5 \times(1.2 \times ; 5)[0.8,0.9]$ wider than long (Figs. 1-4); post-ovarian distance 280-530 (442; 5) [410, 300] or $13-36 \%(27 \% ; 5)$ [n/a, 26\%] of body length (Figs. 1, 3). Oviduct extending posteriad 20-38 $(30 ; 5)[38,20]$ total length or $2 \%(5)$ [n/a, $2 \%$ ] of body length, $8-13(12 ; 5)[10$, 8] wide; oviducal seminal receptacle 50-63 $(55 ; 5)$ [38, $35]$ long or $3-4 \%(3 \% ; 5)$ [n/a, 3\%] of body length, 35-45 $(42 ; 5)[30,30]$ wide or $8-12 \%(9 \% ; 5)[11 \%, 13 \%]$ of maximum body width, oviduct continuing posterosinistrad $20-145(93 ; 5)[55,30]$ or $2-8 \%(5 \% ; 5)[\mathrm{n} / \mathrm{a}, 3 \%]$ of body length, $10-20(15 ; 5)[10,10]$ or $2-5 \%(3 \% ; 5)[\mathrm{n} / \mathrm{a}, 4 \%]$ of maximum body width before connecting with ootype (Figs. 2, 4). Laurer's canal a narrow duct originating 30-43 $(35 ; 5)[25,18]$ or $29-44 \%(33 \% ; 4)[22 \%, 18 \%]$ of ovary length from distal margin of seminal receptacle, extending $20-50(32 ; 5)[45,28]$ or $1-3 \%(2 ; 5)[\mathrm{n} / \mathrm{a}, 2 \%]$ of body length posterosinistrad, $8-20(13 ; 5)[8,13]$ wide or $2-4 \%$ $(3 \% ; 5)[\mathrm{n} / \mathrm{a}, 5 \%]$ of maximum body width.

Vitellarium comprising a series of interconnected spheroid masses of small follicles, distributing from mid-level of oesophagus to caecal terminus, ventrolateral to testes and caeca, terminating $50-190(118 ; 5)[130,108]$ or $3-10 \%$ $(7 \% ; 5)[\mathrm{n} / \mathrm{a}, 9 \%]$ of body length from posterior body end, coalescing into lateral vitelline collection ducts posterior to oviduct (Figs. 2, 4); lateral vitelline collecting ducts 15-20 $(18 ; 4)[20,18]$ in maximum width, coalescing in intercaecal space posterior to ovary and joining at midline to form transverse vitelline duct; transverse vitelline duct $88-130$ $(108 ; 4)[70,58]$ in breadth or $20-29 \%(23 \% ; 4)[25 \%$, $24 \%$ ] of body width at level of middle testis, $15-30(20 ; 4)$ $[15,13]$ in maximum width, 225-505 $(398 ; 5)[350,275]$ or $18-26 \%(23 \% ; 3)[\mathrm{n} / \mathrm{a}, 24 \%]$ of body length from poste- rior body end; primary vitelline duct a narrow duct 13-23 $(19 ; 4)[25,8]$ wide, extending posteriad $43-58(50 ; 4)[45$, $28]$ before curving ventrally, extending $38-53(46 ; 4)$ [58, $25]$ anteriad or $2-3 \%(3 \% ; 4)[\mathrm{n} / \mathrm{a}, 2 \%]$ of body length before merging with female genitalia at oviduct-ootype junction (Figs. 2, 4). Ootype indiscernible from uterus in gravid specimens. Mehlis' gland not observed.

Uterus proximal portion reduced, forming egg chamber with ootype in gravid individuals; egg chamber (ootype + proximal portion of uterus) $42-65(53 ; 5)[62,40]$ long or $40-66 \%(50 \%$; 5) $[54 \%, 40 \%]$ of ovary length, 35-40 (36; 5) $[38,33]$ wide or $19-43 \%(30 \% ; 5)[41 \%, 38 \%]$ of ovary width; metraterm $15-18(17 ; 5)[18,13]$ long or $23-43 \%$ $(33 \% ; 5)[30 \%, 33 \%]$ of egg chamber length, 13-20 (16; 5) $[18,10]$ wide or $33-57 \%(46 \% ; 5)[47 \%, 30 \%]$ of egg chamber width. Uterine egg 55-60 $(57 ; 5)[75,45]$ long or $3-5 \%(3 \% ; 5)[\mathrm{n} / \mathrm{a}, 4 \%]$ of body length, 25-30 (27; 5) [35, $20]$ wide or $11-14 \%(12 \% ; 5)[\mathrm{n} / \mathrm{a}, 18 \%]$ of body width at level of middle testis, $1.8-2.4 \times(2.2 \times ; 5)$ [2.1, 2.3] longer than wide. Common genital pore opening ventral, sinistral (Figs. 1-4), 370-525 (455; 5) [405, 295] or 25-29\% (27\%; 59) $[\mathrm{n} / \mathrm{a}, 26 \%]$ of body length from posterior body end.

Excretory vesicle difficult to discern, 25 (1) $[18,18]$ long or $1 \%(1)[\mathrm{n} / \mathrm{a}, 2 \%]$ of body length, $5-8(7 ; 2)[5,5]$ wide or $2-4 \%(3 \% ; 2)[3 \%, 5 \%]$ of body width at caecal terminus; Manter's organ coiled, turning 7-10 $(8 ; 3)[10$, 3] times, extending between caeca, 128-348 $(226 ; 5)$ [ 250 , 178 ] long or $7-17 \%(13 \% ; 5)$ [n/a, 15\%] of body length, $20-30(25 ; 3)[25,13]$ wide or $9-14 \%(12 \% ; 5)[17 \%$, $12 \%$ of body width at caecal terminus, joining excretory vesicle near excretory pore (Figs. 1,3 ); excretory pore dorsal, $13-15(14 ; 3)[13,13]$ or $1 \%(3)[1 \%, 1 \%]$ from posterior body end (Figs. 1, 3).

Ho st: Deirochelys reticularia (Latreille in Sonnini et Latreille) (Testudines: Emydidae).

Locality: Big Beaver $\left(32^{\circ} 25^{\prime} 44^{\prime \prime N} ; 85^{\circ} 38^{\prime} 45^{\prime \prime} \mathrm{W}\right)$ near Uphapee Creek, Tallapoosa River, near Tuskegee, Alabama, USA.

Site in host: Lung, kidney, body wash.

Intensity: Eight specimens $S$. cf. scripta infected a single chicken turtle.

Specimens deposited: Vouchers (USNM Cat. Nos. 1422047, 1422048); hologenophore (USNM Cat. No. 1422049); GenBank Accession No. KY091666.

Materials examined: See Table 2.

Remarks. We identified our specimens as Spirorchis cf. scripta because they were morphologically similar to museum specimens (holotype, AMNH 128; paratype AMNH 130 ) and published descriptions of S. scripta (see Stunkard 1923, Byrd 1939, Goodchild and Martin 1969, Platt 1993). Noteworthy, however, is that we detected several morphological differences, which, although subtle (i.e. likely comprising intraspecific variation), were seemingly in accord with the slight molecular differences ( $>99 \%$ similarity, 2 of 1263 bases differed) between our specimens and those attributed to S. scripta in GenBank (Fig. 9). Our specimens of $S$. cf. scripta had a proportionally smaller oral sucker (10-18\% of body width vs $27 \%$ in paratype), 
wider oesophagus (12-15\% of body width $v s 7 \%$ in paratype), more narrow oesophageal gland (26-35\% of body width vs $47 \%$ in paratype), compressed middle testis that did not abut the caeca (23-36\% of body width $v s 43 \%$ and $37 \%$, and abutting caeca, in holotype and paratype), more narrow cirrus sac (4-7\% of body width vs $11 \%$ and $15 \%$ in holotype and paratype), longer oviduct (29-44\% of ovary length vs $22 \%$ and $18 \%$ in holotype and paratype), and more narrow uterine eggs (11-14\% of body width vs $18 \%$ in paratype).

After examining the holotype and paratypes as well as newly collected vouchers of $S$. scripta and S. picta from Alabama (Table 1), we accept $S$. picta and differentiate it from $S$. scripta by the combination of having rounded anterior and posterior body ends, a testicular column not abutting the median oesophageal diverticulum, testes that are relatively far separated $(5-30 \mu \mathrm{m}$ apart, with anterior testis separated from second testis [30 $\mu \mathrm{m}, 20 \mu \mathrm{m}])$, and a spherical ovary that is much larger $(3.0 \times$ testis width) than any testis.

Spirorchis scripta has sharply tapered anterior and posterior body ends, a testicular column abutting the caecal bifurcation, testes having abutting or overlapping anterior and posterior margins, and a smaller, lobed ovary (0.7-1.4× testis width). Byrd (1939) considered S. picta a junior subjective synonym of $S$. elegans based on similar body size, gonad and genital pore positions, vitellarium distribution, and testis number. Goodchild and Martin (1969) accepted this synonymy, but also considered $S$. elegans a junior subjective synonym of $S$. scripta because they interpreted testis shape and intercaecal position as ontogenetic and, therefore, unreliable as diagnostic. Platt (1993) rejected that, accepting $S$. elegans as distinct and $S$. picta as a junior subjective synonym of $S$. scripta.

\section{Spirorchis collinsi Roberts et Bullard sp. n. $\quad$ Figs. 6-9}

\section{ZooBank number for species:}

urn:1sid:zoobank.org: act:F629D360-89A5-4B98-8D2C-4A0D27254DF0

Description of adult (based on light microscopy of four adult specimens): Body 2660-3820 (3313; 3) long or $7.2-7.6 \times(7.5 \times ; 3)$ longer than wide, $220-400(328 ; 4)$ wide or $10-11 \%(11 \%$; 3$)$ of body length at level of caecal bifurcation, 335-460 $(394 ; 4)$ wide or $12-13 \%(12 \%$; 3 ) of body length at level of middle testis, 350-500 (430; 4) wide or $13-14 \%(13 \% ; 3)$ of body length at level of Mehlis' gland (typically maximum body width), 245-400 $(328 ; 3)$ wide or $9-12 \%(10 \% ; 3)$ of body length at level of caecal terminus.

Oral sucker $20-33(27 ; 4)$ long or $1 \%(1 \% ; 3)$ of body length, $58-75(67 ; 4)$ wide or $15-30 \%(22 \% ; 4)$ of body width at level of caecal bifurcation (Figs. 6, 7). Nerve commissure $155-200(174 ; 4)$ or $5-6 \%(5 \% ; 4)$ of body length from anterior body end. Pharynx 75-85 $(81 ; 4)$ long or $10-18 \%(15 \% ; 4)$ of oesophagus length, $60-68(64 ; 4)$ wide or $3.0-5.2 \times(4.4 \times ; 4)$ oesophagus width immediately posterior to pharynx (Figs. 6,7$), 1.2-1.3 \times(1.3 \times ; 4)$ longer than wide. Oesophagus extending posteriad 471-780 (559;
4) long or $15-20 \%(18 \% ; 3)$ of body length from mouth to posterior margin of median oesophageal diverticulum, $13-20(15 ; 4)$ wide posterior to pharynx, with wall $8-12$ $(10 ; 4)$ thick, $35-50(44 ; 4)$ wide at oesophagus median or $9-20 \%(14 \% ; 4)$ of body width at level of caecal bifurcation, with wall 25-40 $(33 ; 4)$ thick, 65-90 $(78 ; 4)$ wide anterior to median oesophageal diverticulum or $17-34 \%$ $(25 \%$; 4$)$ of body width at level of caecal bifurcation, with wall 55-70 $(65 ; 4)$ thick; median oesophageal diverticulum $385-660(486 ; 4)$ or $13-17 \%(16 \% ; 3)$ of body length from anterior body end, $58-115(82 ; 4)$ long or $12-16 \%(15 \%$; 4) of oesophagus length, $63-80(70 ; 4)$ wide or $18-31 \%$ $(22 \% ; 4)$ of body width at level of caecal bifurcation; oesophageal gland $280-605(408 ; 4)$ long or $11-16 \%(14 \%$; $3)$ of body length, $105-145(118 ; 4)$ wide or $28-51 \%(38 \%$; 4) of body width at level of caecal bifurcation (Figs. 6, 7).

Intestinal bifurcation $205-730(474 ; 4)$ from anterior body end or $14-19 \%(17 \% ; 3)$ of body length, dorsal to median oesophageal diverticulum; sinistral caecum 2000-3070 $(2533 ; 3)$ long or 73-80\% $(76 \% ; 3)$ of body length, $30-55(40 ; 4)$ wide or $10-14 \%(12 \% ; 4)$ of body width at level of caecal bifurcation, 13-40 (28; 4) wide or $3-9 \%(7 \% ; 4)$ of body width at level of Mehlis' gland, $35-63(48 ; 3)$ wide or $13-16 \%(14 \% ; 3)$ of body width at level of caecal terminus; dextral caecum 1930-2880 $(2450 ; 3)$ long or $73-75 \%(74 \% ; 3)$ of body length, $38-45$ $(43 ; 4)$ wide or $11-20 \%(14 \% ; 4)$ of body width at level of caecal bifurcation, $15-40(28 ; 4)$ wide or $3-10 \%(7 \%$; 4) of body width at level of Mehlis' gland, 35-73 $(49 ; 3)$ wide or $12-18 \%(15 \% ; 3)$ of body width at level of caecal terminus; post-caecal distance $210-370(277 ; 3)$ or $7-11 \%$ $(8 \% ; 3)$ of body length.

Testes $9-10(10 ; 4)$ in number, having abutting or overlapping anterior and posterior margins; testicular column abutting caecal bifurcation or $15-75(38 ; 3)$ or $<1-2 \%$ $(1 \% ; 3)$ of body length from caecal bifurcation, $465-870$ $(684 ; 4)$ long or $20-25 \%(23 \% ; 3)$ of body length; anterior testis (t1) $75-110(91 ; 4)$ long or $2-3 \%(3 \% ; 3)$ of body length, $100-163(123 ; 4)$ wide or $24-38 \%(31 \%$; $)$ of body width at level of middle testis, $1.3-1.5 \times(1.3 \times ; 4)$ wider than long, 5-35 $(19 ; 4)$ from sinistral caecum, abutting or $13-50(28 ; 3)$ from dextral caecum; middle testis (t5) 70-110 (90; 4) long or 3\% (3) of body length, 113-220 $(155 ; 4)$ wide or $32-51 \%(39 \% ; 4)$ of body width at level of middle testis, $1.4-2.0 \times(1.7 \times ; 4)$ wider than long, abutting or $3-25(17 ; 3)$ from sinistral caecum, $8-43(32 ; 4)$ from dextral caecum; posterior-most testis 1520-2380 $(1980 ; 3)$ or $57-62 \%(59 \% ; 3)$ of body length from posterior body end, $50-103(81 ; 4)$ long or $2-3 \%(3 \% ; 3)$ of body length, $130-240(171 ; 4)$ wide or $37-56 \%(43 \% ; 4)$ of body width at level of middle testis, $1.8-2.6 \times(2.2 \times ; 4)$ wider than long, abutting or 5-10 $(7 ; 3)$ from sinistral caecum, 5-30 (18; 4) from dextral caecum (Fig. 7).

Vas deferens $375-730(523 ; 4)$ long or $11-21 \%(18 \%$; $3)$ of body length, $8-15(12 ; 4)$ wide, ventral to testicular column, laterally expanding before joining external seminal vesicle posterior to testes (Figs. 7, 8); external seminal vesicle $75-190(121 ; 4)$ long or $3-5 \%(4 \% ; 3)$ of body length, $140-195(160 ; 4)$ wide or $32-40 \%(37 \% ; 4)$ 
of body width at level of Mehlis' gland, $0.5-1.2 \times(0.8 \times$; 4) longer than wide (Figs. 7, 8); internal seminal vesicle $155-243(179 ; 4)$ long or $4-9 \%(6 \% ; 3)$ of body length, $38-50(44 ; 4)$ maximum width or $36-84 \%(62 \% ; 4)$ of cirrus sac width, $3.2-6.4 \times(4.2 \times ; 4)$ longer than wide (Fig. 8); proximal portion of internal seminal vesicle $33-50(39 ; 4)$ long or $14-31 \%(23 \% ; 4)$ of total internal seminal vesicle length, 25-50 $(38 ; 4)$ wide; distal portion of internal seminal vesicle $113-210(141 ; 4)$ long or $69-86 \%(77 \%$; 4$)$ of total internal seminal vesicle length, $38-48(42 ; 4)$ wide. Cirrus sac $188-250(210 ; 4)$ long or $5-7 \%(6 \% ; 3)$ of body length, 45-135 $(79 ; 4)$ wide or $12-27 \%(18 \%$; 4$)$ of body width at level of Mehlis' gland; cirrus massive, sinuous, $148-333(233 ; 4)$ long or $6-9 \%(7 \% ; 3)$ of body length, $15-55(35 ; 4)$ wide or $4-11 \%(8 \% ; 4)$ of maximum body width.

Ovary spheroid, lacking lobes, intercaecal, posterior to cirrus sac, $70-165(113 ; 4)$ long or $3-4 \%(4 \% ; 3)$ of body length, $103-130(118 ; 4)$ wide or $26-29 \%(28 \% ; 4)$ of body width, $0.8-1.6 \times(1.1 \times ; 4)$ wider than long (Figs. 7,8$)$; post-ovarian distance $1290-1900(1643 ; 3)$ or $48-50 \%$ $(50 \% ; 3)$ of body length (Fig. 7). Oviduct extending posteriad 25-35 $(30 ; 4)$ or $1 \%$ (3) of body length, 13-20 (15; 4) wide; oviducal seminal receptacle $45-60(53 ; 4)$ long or $1-2 \%(2 \% ; 3)$ of body length, $30-45(38 ; 4)$ wide or $8-11 \%(9 \% ; 4)$ of maximum body width, oviduct continuing posterosinistrad $83-150(116 ; 4)$ or $1-4 \%(2 \% ; 3)$ of body length, $10-20(17 ; 4)$ wide or $3-5 \%(4 \% ; 4)$ of maximum body width before connecting with ootype (Fig. 8). Laurer's canal a narrow duct originating $25-75(46 ; 4)$ or $34-46 \%(40 \% ; 4)$ of ovary length from distal margin of seminal receptacle, extending $60-80(69 ; 4)$ or $2 \%(3)$ of body length posterosinistrad, $13-35(19 ; 4)$ wide or $3-7 \%$ $(4 \% ; 4)$ of maximum body width.

Vitellarium comprising a series of interconnected spheroid masses of small follicles (Fig. 7), distributing from caecal bifurcation to caecal terminus, ventral to caeca and testis anteriorly and flanking caeca posteriorly, terminating $155-350(237 ; 3)$ or $5-10 \%(7 \% ; 3)$ of body length from posterior body end, coalescing into lateral vitelline collection ducts posterior to oviduct; lateral vitelline collecting ducts $13-25(20 ; 4)$ in maximum width, coalescing in intercaecal space posterior to ovary and joining at midline to form transverse vitelline duct; transverse vitelline duct $113-225(155 ; 4)$ in breadth or $29-45 \%(36 \% ; 4)$ of body width at level of Mehlis' gland, 13-25 $(19 ; 4)$ in maximum width, $1170-1740(1513 ; 3)$ or $44-47 \%(46 \% ; 3)$ of body length from posterior body end (Figs. 7,8$)$; primary vitelline duct a narrow duct $23-55(42 ; 4)$ wide, extending posteriad $25-75(49 ; 4)$ before curving ventrally, extending $25-100(58 ; 4)$ anteriad or $1-3 \%(2 \% ; 3)$ of body length before merging with female genitalia at oviduct-ootype junction (Fig. 8). Ootype 38-75 $(53 ; 4)$ long or $41-54 \%$ $(48 \% ; 4)$ of ovary length, $13-40(22 ; 4)$ wide or $12-31 \%$ $(18 \% ; 4)$ of ovary width (Fig. 8). Mehlis' gland obvious, $125-320(199 ; 4)$ long or $4-8 \%(7 \% ; 3)$ of body length, $170-270(199 ; 4)$ wide or $35-54 \%(46 \% ; 4)$ of body width (Figs. 7, 8).
Uterus comprising metraterm only (Fig. 8); metraterm apparently comprising the entire length of the uterus from ootype extending anteriad, 218-375 $(280 ; 4)$ long or $7-10 \%(8 \% ; 3)$ of body length, $25-60(36 ; 4)$ wide or $6-12 \%(8 \% ; 4)$ of maximum body width, wall 20-22 (21; 4) wide, dorsal to cirrus (Fig. 8). Uterine egg absent. Common genital pore $1460-2160(1847 ; 3)$ or $55-57 \%(56 \%$; 3 ) of body length from posterior body end (Fig. 7).

Excretory vesicle $30-45(35 ; 3)$ long or $1 \%(3)$ of body length, $10-15(13 ; 3)$ wide or $3-6 \%(4 \% ; 3)$ of body width at caecal terminus; Manter's organ turning 3-10 (7; 3) times proximally, sinuous distally, intercaecal, 385-500 $(425 ; 3)$ long or $11-14 \%(13 \% ; 3)$ of body length, $35-60$ $(45 ; 3)$ wide or $12-15 \%(14 \% ; 3)$ of body width at level of caecal terminus, joining excretory vesicle at excretory pore (Fig. 7); excretory pore dorsal, $25-45(35 ; 3)$ or $1-2 \%$ $(1 \% ; 3)$ from posterior body end (Fig. 7).

Type and only known host: Chicken turtle, Deirochelys reticularia (Latreille in Sonnini et Latreille) (Testudines: Emydidae)

Type 1 o c a lity: Big Beaver Pond $\left(32^{\circ} 25^{\prime} 44^{\prime \prime N}\right.$; $\left.85^{\circ} 38^{\prime} 45^{\prime \prime} \mathrm{W}\right)$ near Uphapee Creek, Tallapoosa River, near Tuskegee, Alabama, USA.

O the r 1 o c a lity: Salt Pond ( $\left.31^{\circ} 10^{\prime} 14^{\prime \prime N} ; 86^{\circ} 32^{\prime} 18^{\prime \prime W}\right)$, Yellow River, near Andalusia, Alabama, USA.

Site in host: Kidney blood vessels and body wash.

Prevalence and intensity of infection: Two $(100 \%)$ chicken turtles were infected by four and two specimens of $S$. collinsi, respectively.

Specimens/materials deposited: Holotype (USNM Cat. No. 1422045); hologenophore (USNM Cat. No. 1422046); paratype (IPCAS Cat. No. D-733); GenBank Accession No. KY091664.

Ety mology: The specific epithet collinsi is in gratitude to Dr. Michael D. Collins (Department of Biological Sciences, Rhodes College, Memphis, Tennessee, USA) for mentoring JRR during his Bachelor's degree program.

Remarks. The new species is most easily differentiated from its congeners by the combination of having caeca that extend far beyond the genitalia, intercaecal genitalia positioned in the middle portion of the body, a testicular column that nearly abuts the caecal bifurcation, a cirrus sac positioned between the testes and ovary, a massive Mehlis' gland, an elongate, longitudinal metraterm that extends anteriad beyond the level of the ovary, a pre-ovarian genital pore and a prominent, intercaecal Manter's organ.

The new species resembles S. scripta, S. elegans, $S$. innominatus, and $S$. artericola by having a testicular column that is positioned such that its anterior-most testis is close to the caecal bifurcation. However, the most obvious feature that differentiates the new species from these and other congeners is the mid-body position of the genitalia. Further, S. haematobius has a post-ovarian genital pore; $S$. kir$k i$ has four or five testes, a post-ovarian genital pore, indiscernible Mehlis' gland, and no Manter's organ; S. minutus has a testicular column that does not abut the caecal bifurcation, genitalia in the posterior $1 / 5$ of body, and an ovary that is lateral to the cirrus sac and genital pore; $S$. parvus 
has four or five testes, a post-ovarian genital pore, an indiscernible Mehlis' gland, and a postcaecal Manter's organ; and S. picta has an ovary that abuts the testis.

The phylogenetic analysis of the $28 \mathrm{~S}$ sequence data indicated that $S$. collinsi and $S$. picta were sister taxa within a clade that included $S$. haematobius, $>99 \%$ (2 of 1263 bases differed) similarity between $S$. cf. scripta and S. scripta, and a monophyletic Spirorchis (Fig. 9). Members of the $S$. haematobius clade have a prominent median oesophageal diverticulum, ten testes, a cirrus sac positioned between the testes and ovary, a spheroid, non-lobed ovary, an obvious Mehlis' gland, and an intercaecal Manter's organ. Spirorchis collinsi and S. picta have a Mehlis' gland that fills the intercaecal space from the level of the ovary to the anterior margin of the transverse vitelline duct (Fig. 8). Stunkard (1923) did not detail a Mehlis' gland in S. picta, and the holotype and paratype are poorly stained (perhaps destained); however, our specimens have an obvious Mehlis' gland similar to that of $S$. collinsi. Some of the museum specimens of $S$. haematobius we examined appeared to show intraspecific variation in ovary shape: being weakly lobed to spheroid. Ulmer (1959) suspected that the lobes resulted from excessive coverslip pressure (see Ulmer's [1959] figures 2-10, p. 83).

\section{DISCUSSION}

In addition to being a never-before-reported TBF host, the chicken turtle was a high priority target for TBF sampling because of its phylogenetic position within Emydidae (van Dijk et al. 2014, Spinks et al. 2016) and because of its overwintering behavior (Buhlmann 2005, Guyer et al. 2015). Deirochelys Agassiz is monotypic, comprises an early branching lineage within Deirochelyinae Agassiz (Chrysemys Gray, Deirochelys, Graptemys Agassiz, Malaclemys Gray, Pseudemys Gray, Trachemys Agassiz), and is the sister taxon to all other deirochelyines. Hence, we anticipated that this phylogenetically distinct turtle lineage would harbor new TBF taxa. Regarding overwintering behavior, of all reported turtle hosts for Spirorchis spp., D. reticularia and the western pond turtle, Actinemys marmorata Baird et Girard (see Thatcher 1954), are the only species that reportedly primarily overwinter terrestrially (Reese and Welsh 1997, Rathbun et al. 2002, Buhlmann 2005, Ernst and Lovich 2009, Guyer et al. 2015). Such extended, annual, terrestrial forays suggest that perhaps these TBFs have increased adult longevity to maximise egg release when the turtles return to water in spring. Terrestrial aestivation during colder months by chicken turtles differs from that of pond sliders, Trachemys scripta (the type host for S. scripta), which overwinter in aquatic shelters (e.g. submerged logs, scour habitat, and river or pond banks) (Bodie and Semlitsch 2000, Ryan et al. 2008, Ernst and Lovich 2009). Perhaps these host behaviours are reflected by divergent parasite life history strategies, which may have resulted in genetic isolation and subtle morphological differences among these TBFs. Intensive, seasonal sampling of these ecologically different turtle species for TBF infections, genetic comparisons among the resulting TBFs and identification of the TBF intermediate hosts could help test the hypothesis that ecological differences between turtle hosts result in TBF genetic isolation and morphological divergence. We suspect that the TBFs of chicken turtles and pond sliders may comprise a good model system with which to test such a hypothesis. Noteworthy regarding TBF-turtle cophylogeny, or rather the apparent lack thereof, although Spirorchis haematobius, S. collinsi and Vasotrema spp. reportedly exhibit a high degree of host specificity, the TBF clade (Roberts et al. 2016a) and the Spirorchis clade (Fig. 9) are not concordant with recent turtle phylogenies (Guillon et al. 2014, Spinks et al. 2016). Yet, few TBFs have been included in molecular phylogenies and additional TBF taxon sampling will help further test TBF-turtle cophylogeny.

Tkach et al. (2009), Orélis-Ribeiro et al. (2014) and Roberts et al. (2016a,b) provided molecular phylogenetic analyses that recovered a paraphyletic Spirhapalum, with Spirhapalum polesianum Ejsmont, 1927 sister to Spirorchis spp. + Spirorchis siamensis Tkach, Snyder et Vaughn, 2009. Tkach et al. (2009) considered proposing a new genus for $S$. siamensis but lacked morphological details to justify it. Spirhapalum siamensis and Spirhapalum elongatum Rohde, Lee et Lim, 1968 infect Cuora amboinensis (Riche in Daudin), an Asian geoemydid, whereas, S. polesianum was reported from Emys orbicularis (Linnaeus), an early branching emydid (Rohde et al. 1968, Brooks and Palmieri 1979, Snyder 2004, Tkach et al. 2009, Spinks et al. 2016). The phenomenon of congeneric TBFs infecting turtles of multiple families is exemplified by Cardiotrema spp. infecting geoemydids and trionychids, Spirorchis spp. infecting chelydrids and emydids, and Hapalorhynchus spp. infecting chelydrids, kinosternids, geoemydids and pelomedusids. Collectively, this suggests either low host specificity of the TBFs comprising these genera or the presence of new TBF genera. However, inaccessibility (or nonexistence) of museum material for all TBFs from the Indian subcontinent (see Platt 2002) remains a major block to exploring the taxonomy and systematics of this group of blood flukes.

Acknowledgements. We thank Brian Folt and Jeffrey Goessling (Auburn University) helping collect turtles; Thomas R. Platt for his donation of his library and specimen collection, which provided invaluable reference specimens for study and comparison; and Estefania Rodriguez (AMNH), Anna Philips (USNM), Chad Walter (USNM) and William Moser (USNM) for loaning museum specimens. The present study is a contribution of the Southeastern Cooperative Fish Parasite and Disease Project (Auburn University) and was supported in part by grants from the National Science Foundation Division of Environmental Biology via grant nos. 1112729,1051106 and 1048523 awarded to SAB. 


\section{REFERENCES}

Anonymous. 1919: Twenty-third Annual Report of the New York Zoological Society. Clark and Fritts Printers, New York, 204 pp.

Bodie J.R., Semlitsch R.D. 2000: Spatial and temporal use of floodplain habitats by lentic and lotic species of aquatic turtles. Oecologia 122: 138-146.

Brooks D.R., Palmieri J.R. 1979: Neopronocephalus orientalis sp. n. (Digenea: Pronocephalidae) and Spirhapalum elongatum Rohde, Lee, and Lim, 1968 (Digenea: Spirorchiidae) from Cuora amboinensis (Daudin) in Malaysia. Proc. Helminthol. Soc. Wash. 46: 55-57.

Buhlmann K.A. 2005: Habitat use, terrestrial movements, and conservation of the turtle, Deirochelys reticularia in Virginia. J. Herpetol. 29: 173-181.

Bullard S.A. 2012: A new aporocotylid (Digenea) species from blood vascular system of gag grouper, Mycteroperca microlepis (Perciformes: Serranidae), off Alabama, with an emendation of Pearsonellum Overstreet \& Køie, 1989. J. Parasitol. 98: 323-327.

Bullard S.A. 2013: Cardicola langeli n. sp. (Digenea: Aporocotylidae) from heart of sheepshead, Archosargus probatocephalus, (Actinopterygii: Sparidae) in the Gulf of Mexico, with an updated list of hosts, infection sites and localities for Cardicola spp. Folia Parasitol. 60: 17-27.

Bullard S.A, Snyder S.D., Jensen K., Overstreet R.M. 2008: New genus and species of Aporocotylidae (Digenea) from a lower actinopterygian, the American paddlefish, Polyodon spathula, (Polyodontidae) from the Mississippi Delta. J. Parasitol. 94: 487-495.

BYRD E.E. 1939: Studies on the blood flukes of the family Spirorchidae. Part II. Revision of the family and description of new species. J. Tenn. Acad. Sci. 14: 116-161.

van Dijk P.P., Iverson J.B., Rhodin A.G. J., Shaffer H.B., Bour R. 2014: Turtles of the world. Seventh Edition. Annotated checklist of taxonomy, synonymy, distribution with maps, and conservation status. Chel. Res. Monogr. 5: 329-479.

EJSMONT L. 1927: Spirhapalum polesianum n. g., n. sp. trématode du sang d'Emys orbicularis L. Ann. Parasitol. Hum. Comp. 5: 220-235.

Ernst C.H., Lovich J.E. 2009: Turtles of the United States and Canada. Second Edition. The Johns Hopkins University Press, Baltimore, Maryland, $827 \mathrm{pp}$.

Goodchild C.G., KiRK D.E. 1960: The life history of Spirorchis elegans Stunkard, 1923 (Trematoda: Spirorchiidae) from the painted turtle. J. Parasitol. 46: 219-229.

Goodchild C.G., Martin V.L. 1969: Speciation in Spirorchis (Trematoda: Spirorchiidae) infecting the painted turtle, Chrysemys picta. J. Parasitol. 55: 1169-1173.

Guillon J., Guéry L., Hulin V., Girondot M. 2012: A large phylogeny of turtles (Testudines) using molecular data. Contr. Zool. 81: 147-158.

Gupta N.K., Mehrotra V. 1975: On three blood flukes (Spirorchiidae: Spirorchiinae) from freshwater chelonians and discussion on the synonymy of Plasmiorchis pellucidus Mehra, 1934. Riv. Parassitol. 36: 165-170.

Guyer C., Bailey M.A., Mount R.H. 2015: Turtles of Alabama, The University of Alabama Press, Tuscaloosa, Alabama, 266 pp.

Holliman R.B., Fisher J.E. 1968: Life cycle and pathology of Spirorchis scripta Stunkard, 1923 (Digenea: Spirochiidae) in Chrysemys picta picta. J. Parasitol. 54: 310-318.

Holliman R.B., Fisher J.E., Parker J.C. 1971: Studies on Spirorchis parvus (Stunkard, 1923) and its pathological effects on Chrysemys picta picta. J. Parasitol. 57: 71-77.

Johnson P.D., Bogan A.E., Brown K.M., Burkhead N.M., Cordeiro J.R., Garner J.T., Hartfield P.D., LepitzKi D.A.W., Mackie G.L., Pip E., Tarpley T.A., TiemanN J.S., Whelan N.V., Strong E.E. 2013: Conservation status of freshwater gastropods of Canada and the United States. Fisheries. 38: $247-282$.
Lockyer A.E., Olson P.D., Ostergahd P., Rollinson D., Johnston D.A., Attwood S.W., Southgate V.R., Horák P., Snyder S.D., Le T.H., Agatsuma T., McManus D.P., Carmichael A.C., Naem S., Littlewood D.T.J. 2003: The phylogeny of the Schistosomatidae based on three genes with emphasis on the interrelationships of Schistosoma Weinland, 1858. Parasitology 126: 203-224.

MacCallum G.A. 1918: Notes on the genus Telorchis and other trematodes. Zoopathologica 1: 77-98.

MaCCallum G.A. 1926: Revue du genre Spirorchis MacCallum. Ann. Parasitol. Hum. Comp. 4: 97-103.

McVay M.J., Bakenhaster M.D., Bullard S.A. 2011: Cardicola laruei Short, 1953 (Digenea: Aporocotylidae) from heart of seatrouts, Cynoscion spp., (Perciformes: Sciaenidae) in the Gulf of Mexico and Atlantic Ocean: taxonomic redescription, first observations of egg and miracidium, and comments on geographic distribution and host specificity. Comp. Parasitol. 78: 291-305.

Menra H.R. 1934: New blood flukes of the family Spirorchidae Stunkard from Indian fresh-water tortoises with discussion on the synonymy of certain genera and the relationships of the families of blood flukes. Part II. Bull. Acad. Sci. United Prov. Agra Oudh 3: 169-196.

Menra H.R. 1939: New blood flukes of the family Spirorchidae Stunkard (Trematoda) from the marine turtle Chelone mydas of the Arabian Sea with observations on the synonymity of certain genera and classification of the family. Proc. Nat. Acad. Sci. India 9: $155-167$.

Olson P.D., Cribb T.H., Tkach V.V., Bray R.A., Littlewood D.T.J. 2003. Phylogeny and classification of the Digenea (Platyhelminthes: Trematoda). Int. J. Parasitol. 33: 733-755.

Orélis-Ribeiro R., Arias C.R., Halanych K.M., Cribb T.H., BULLARD S.A. 2014: Diversity and ancestry of flatworms infecting blood of nontetrapod craniates "fishes." Adv. Parasitol. 85: $1-64$.

PiePer M.B. 1953: The life history and germ cell cycle of Spirorchis artericola (Ward, 1921). J. Parasitol. 39: 310-325.

Platt T.R. 1990: Aphanospirorchis kirki n. gen., n. sp. (Digenea: Spirorchidae), a parasite of the midland painted turtle, Chrysemys picta marginata, from northwestern Indiana, with comments on the proper spelling of the family name. J. Parasitol. 76: $650-652$.

Plate T.R. 1992: A phylogenetic and biogeographic analysis of the genera of Spirorchinae (Digenea: Spirorchidae) parasitic in freshwater turtles. J. Parasitol. 78: 616-629.

Platt T.R. 1993: Taxonomic revision of Spirorchis MacCallum, 1919 (Digenea: Spirorchidae). J. Parasitol. 79: 337-346.

Platt T.R. 2002: Family Spirorchiidae Stunkard, 1921. In: D.I. Gibson, A.J. Jones and R.A. Bray (Eds.), Keys to the Trematoda, Vol. 1. CABI, Wallingford, 453-467 pp.

Price E.W. 1934: New genera and species of blood flukes from a marine turtle, with a key to the genera of the family Spirorchidae. J. Wash. Acad. Sci. 24: 132-141.

Rathbun G.B., Scott Jr. N.J., Murphey T.G. 2002: Terrestrial habitat use by Pacific pond turtles in a Mediterranean climate. Southwest. Nat. 47: 225-235.

Reese D.A., Welsh H.H. 1997: Use of terrestrial habitat by western pond turtles, Clemmys marmorata: implications for management. In: Proceedings: Conservation, Restoration, and Management of Tortoises and Turtles-An International Conference. New York Turtle and Tort. Soc. New York City, New York, pp. 352-357.

Roberts J.R., Orélis-Ribeiro R., Dang B.T., Halanych K. M., Bullard S.A. 2016b: Blood flukes of Asiatic softshell turtles: revision of Coeuritrema Mehra, 1933 (Digenea: Schistosomatoidea) and a new species infecting Chinese softshell turtles, Pelodiscus sinensis, (Trionychidae) from the Da Rang River, Vietnam. Folia Parasitol. 63: 031 
Roberts J.R., Platt T.R., Orélis-Ribeiro R., Bullard S.A. 2016a: New genus of blood fluke (Digenea: Schistosomatoidea) from Malaysian freshwater turtles (Geoemydidae) and its phylogenetic position within Schistosomatoidea. J. Parasitol. 102: 451-462.

Rohde K., Lee S. K., Lim H.W. 1968: Ueber drei malayische Trematoden. Ann. Parasitol. Hum. Comp. 43: 33-43.

Ryan T.J, Conner C.A., Douthitt B.A., Sterrett S.C., SAlSBURY C.M. 2008: Movement and habitat use of two aquatic turtles (Graptemys geographica and Trachemys scripta) in an urban landscape. Urban Ecosyst. 11: 213-225.

SinHA B.B. 1934: A new genus of blood flukes of the family Spirorchidae, from the tortoise, Hardella thurgi (Gray). Rec. Ind. Mus. 36: 147-151.

Sмiтн J.W. 1997a: The blood flukes (Digenea: Sanguinicolidae and Spirorchidae) of cold-blooded vertebrates: Part I. A review of the literature published since 1971, and bibliography. Helminthol. Abstr. 66: 255-294.

Sмiтн J.W. 1997b: The blood flukes (Digenea: Sanguinicolidae and Spirorchidae) of cold-blooded vertebrates: Part II. Appendix I: Comprehensive parasite-host list; Appendix II: Comprehensive host-parasite list. Helminthol. Abstr. 66: 329-344.

SNYDER S.D. 2004. Phylogeny and paraphyly among tetrapod blood flukes (Digenea: Schistosomatidae and Spirorchiidae). Int J. Parasitol. 34: 1385-1392.

Spinks P.Q., Thomson R.C., McCartney-Melstad E., ShafFER H.B. 2016: Phylogeny and temporal diversification of the New World pond turtles (Emydidae). Mol. Phylogenet. Evol. 103: 85-97.
STUNKARD H.W. 1922: Two new genera of North American blood flukes. Am. Mus. Novit. 39: 1-8.

Stunkard H.W. 1923: Studies on North American blood flukes. Bull. Am. Mus. Nat. Hist. 48: 165-221.

Thatcher V.E. 1954: Some helminthes parasitic in Clemmys marmorata. J. Parasitol. 40: 481-482.

Tkach V., Snyder S.D., Vaughan J.A. 2009: A new species of blood fluke (Digenea: Spirorchiidae) from the Malayan box turtle, Cuora amboinensis (Cryptodira: Geoemydidae) in Thailand. J. Parasitol. 95: 743-746.

Truong T.N., Bullard S.A. 2013: Blood flukes (Digenea: Aporocotylidae) of walking catfishes (Siluriformes: Clariidae): new genus and species from the Mekong River (Vietnam) and note on catfish aporocotylids. Folia Parasitol. 60: 237-247.

Ulmer M.J. 1959: Studies on Spirorchis haematobium (Stunkard, 1922) Price, 1934 (Trematoda: Spirorchiidae) in the definitive host. Trans. Am. Microsc. Soc. 78: 81-89.

WALl L.D. 1939: Life history of Spirorchis sp. (Trematoda: Spirorchiidae). J. Parasitol. 25: 28.

WALL L.D. 1940: Life history of Spirorchis parvus (Stunkard) Trematoda: Spirorchiidae. Science 92: 362-363.

WALl L.D. 1941a: Life history of Spirorchis elephantis (Cort, 1917), a new blood fluke from Chrysemys picta. Am. Midl. Nat. 25: 402-412.

WALL L.D. 1941b: Spirorchis parvus (Stunkard) its life history and the development of its excretory system (Trematoda: Spirorchiidae). Trans. Am. Microsc. Soc. 60: 221-260.

Ward H.B. 1921: A new blood fluke from turtles. J. Parasitol. 114-128.

Cite this article as: Roberts J.R., Orélis-Ribeiro R., Halanych K.M., Arias C.R., Bullard S.A. 2016: A new species of Spirorchis MacCallum, 1918 (Digenea: Schistosomatoidea) and Spirorchis cf. scripta from chicken turtle, Deirochelys reticularia (Emydidae), with an emendation and molecular phylogeny of Spirorchis. Folia Parasitol. 63: 041. 